\title{
Energy-Efficient Procurement in State and Local Government
}

July 1979

Prepared for:

U.S. Department of Energy

Assistant Secretary for Conservation and Solar Applications State Energy Conservation Programs

Contract No. EM-78-C-01-5255 


\section{DISCLAIMER}

This report was prepared as an account of work sponsored by an agency of the United States Government. Neither the United States Government nor any agency Thereof, nor any of their employees, makes any warranty, express or implied, or assumes any legal liability or responsibility for the accuracy, completeness, or usefulness of any information, apparatus, product, or process disclosed, or represents that its use would not infringe privately owned rights. Reference herein to any specific commercial product, process, or service by trade name, trademark, manufacturer, or otherwise does not necessarily constitute or imply its endorsement, recommendation, or favoring by the United States Government or any agency thereof. The views and opinions of authors expressed herein do not necessarily state or reflect those of the United States Government or any agency thereof. 


\section{DISCLAIMER}

Portions of this document may be illegible in electronic image products. Images are produced from the best available original document. 


\section{Energy-Efficient Procurement in State and Local Government}

July 1979

Prepared by:

Joe W. Russell, Jr.

Environmental Law Institute

Washington, D.C. 20036

Prepared for:

U.S. Department of Energy

Assistant Secretary for Conservation and Solar Applications State Energy Conservation Programs

Washington, D.C. 20585

Contract No. EM-78-C-01-5255

This repon was prepared as an account of work sponsored by the United States Government. Neither the United States nor the United States Department of Energ, nor any of their employees, nor any of their Energy, nor any of cheir employes, nor any of their contractors, subcontracton, or uheir employees, makes any wartanty, express or implied, or assumes any legal liability of responsibility for the accurscy, completeness or usefulness of any information, apparatus, product or process disclosed, or represents that its use would not infringe privately owned rights. 


\section{NOTICE}

This report was prepared as an account of work sponsored by the United States Government. Neither the United States nor the United States Department of Energy, nor any of their employees, makes any warranty, express or implied, or assumes any legal liability or responsibility for the accuracy, completeness, or usefulness of any information, apparatus, product, or process disclosed, or represents that its use would not infringe privately owned rights. Reference herein to any specific commercial product, process, or service by trode name, mark, manufacturer, or otherwise, does not necessarily constitute or imply its endorsement, recommendation, or favoring by the United States Government or any agency thereof. The views and opinions of authors expressed herein do not necessarily state or reflect those of the United States Government or any agency thereof. 
TABLE OF CONTENTS

SUMMARY iii

ACKNOWLEDGMENTS V v

INTRODUCTION AND OVERVIEW 1

LEGAL FRAMEWORK OF ENERGY-EFFICIENT

PROCUREMENT

Lowest Bid Provisions and Life Cycle Costing 4

Mandates for Energy-Efficient Procurement $\quad 5$

$\begin{array}{ll}\text { Executive Orders } & 6\end{array}$

Statutory Mandates $\quad 7$;

Mandates Concerning Buildings, Automobiles, and Recycled Paper

INSTITUTIONAL FRAMEWORK OF ENERGY-EFFICIENT PROCUREMENT

Decentralized Purchasing Systems

Achieving Energy-Efficient Procurement in

Decentralized Purchasing Systems

The State Role in Energy-Efficient Procurement by Local Governments

THE INFORMATION GAP

FUTURE OPPORTUNITIES IN ENERGY-EFFICIENT

PROCUREMENT

$\begin{array}{lr}\text { CONCLUSION } & 27\end{array}$

$\begin{array}{lr}\text { NOTES } & 28\end{array}$

$\begin{array}{ll}\text { BIBLIOGRAPHY } & 34\end{array}$

$\begin{array}{ll}\text { TECHNICAL APPENDIX } & 36\end{array}$ 


\section{SUMM AR Y}

As the prices of domestically produced and imported energy continue to skyrocket, the need for increased efforts to save energy grows almost daily. While states and their political subdivisions can encourage energy conservation in a variety of ways, they can set an example for their citizens and save energy themselves by becoming more conscious of the energy impacts of government purchasing and more committed to energy-efficient procurement.

This report examines the progress made by states in this area since the enactment in 1975 of the Energy Policy and Conservation Act (EPCA). One part of this law authorizes federal assistance to states for the preparation and implementation of energy conservation plans to include, among other elements, energy-efficient procurement standards and policies. Three and a half years after EPCA's passage, state and local energyefficient procurement programs, with a few exceptions, have barely advanced beyond infancy. The major reasons for this are a lack of reliable energy efficiency information on many energy-consuming products, a resistance to change on the part of purchasing officials or their superiors, and a reluctance in the tax revolt era to spend money in order to save money as well as energy.

To overcome these obstacles, states and localities should consider mandating energy-efficient procurement practices through either executive orders or legislation. In addition, states and localities should consider adopting institutional arrangements, such as centralized purchasing and joint or cooperative purchasing that will facilitate energy-efficient procurement. 
Finally, to further state and local efforts in this area, the federal government should provide technical and financial assistance to an organization of purchasing officials to establish an information clearinghouse. Closing the information gap is perhaps the most effective action the federal government could take to promote energy-efficient procurement by state and local governments. 


\section{ACKNOWLEDGMENTS}

Wendy Smith and Laura Hedal, research associates at the Environmental Law Institute, contributed greatly to this project by assembling relevant information. Ivan J. Tether, author of Government Procurement and Operations (Cambridge, Mass.: Ballinger, 1977) served as a consultant and helped keep the research on track.

Experts who provided incisive comments on a draft of this report include: Larry Ethridge, Assistant Project Director, American Bar Association Model Procurement Code Project; Richard Keller, Maryland Energy Policy Office; Robert M. Lohrenz, Supervisor, Standards and Specifications, Illinois Department of Administrative Services; James F. Runke, Council of State Governments; and Joseph J. Warnas, Director, Department of Materials Management, Maricopa County, Arizona.

Richard Klimkos of the Office of State Energy Conservation Programs, U.S. Department of Energy, was project officer. 
INTRODUCTION AND OVER VIEW

The Arab oil embargo of 1973-74 and the crisis it generated marked the passing of an era in which the United States enjoyed the benefits of cheap and abundant energy. In 1979, disruption in the world oil markets caused by the political upheaval in Iran and substantial price increases announced by the Organization of Petroleum Exporting Countries are indicative of the uncertainty and expense that darken America's energy future. In the search for policies to cope with these new realities, attention has centered on energy conservation. Congress emphasized the importance of conservation by passing the Energy Policy and Conservation Act (EPCA) in late 1975. ${ }^{1}$ One of EPCA's objectives is to encourage the states to become more involved in the conservation effort. To this end, Congress authorized federal technical and financial assistance to states to prepare and implement state energy conservation plans. ${ }^{2}$ in order to receive federal assistance, states must include five elements in their plans. One of the five program measures is "mandatory standards and policies relating to energy efficiency to govern the procurement practices of [the] State and its political subdivisions." ${ }^{3}$

The Congressional conference report on EPCA does not enumerate the reasons for including state and local government procurement among the mandatory program measures. Several reasons for its selection, however, spring readily to mind. As major users of many energy-consuming goods and services, state and local governments can substantially reduce their energy needs (and save money over the long run) by purchasing the more energyefficient items from among those available. Energy-conscious purchasing 
also underlines a government's commitment to deal with the nation's energy problem through conservation and sets an example for the private sector to follow. Moreover, by creating a market for energy-efficient commodities, state and local governments can stimulate efforts by manufacturers and suppliers to improve the energy efficiency of their products.

Following the enactment of EPCA, the Federal Energy Administration (now the Department of Energy) issued regulations to guide the states in preparing their energy conservation plans. The regulations established minimum criteria for the plans' mandatory program measures. For procurement, the regulations simply required that the plans "contain the elements deemed appropriate by the State to improve energy efficiency through the procurement practices of the State and its political subdivisions." ${ }^{4}$ Exercising the discretion allowed by these permissive guidelines, states developed a variety of procurement programs. Some states (e.g., Illinois) proposed detailed, ambitious plans that incorporated a number of innovative procurement strategies. Most states, however, prepared rather limited plans (e.g., proposing to buy automobiles and air conditioners on a life cycle cost basis and to provide information and training services to local purchasing officials). Three years after the passage of EPCA, a few states (e.g. Kentucky, North Carolina and Wyoming) have fairly advanced energyefficient procurement programs, while the majority have only begun to employ energy-saving procurement practices. ${ }^{5}$

At the request of the Department of Energy's Office of State Energy Conservation Programs, the Environmental Law Institute has examined state and local efforts to implement energy-efficient procurement programs. The Institute sought information on these programs from state energy offices, 
state purchasing offices, and the purchasing offices of selected cities and counties. $^{6}$. A draft report from a study of state programs by the Council of State Governments was used to supplement the information we obtained. ${ }^{7}$ In analyzing this information, we focused both on what states and localities have achieved and on what they have failed to accomplish. As for the latter, we sought to discover whether particular legal or institutional factors have slowed progress in the implementation of energy-efficient procurement strategies:

Our research led us to five observations:

- There are no universal legal impediments (i.e., constitutional provisions, laws or legal doctrines) preventing states and localities from implementing energy-efficient procurement programs.

- An affirmative mandate, in the form of an executive order from the governor or a statute enacted by the legislature, may be necessary to provide an impetus to the adoption of energyefficient procurement practices.

- In jurisdictions with decentralized purchasing systems, centralized purchasing should be considered, at least for major energy-consuming commodities. Alternatively, energy-efficient procurement standards could be imposed.

- States should encourage or mandate increased joint or cooperative purchasing of major energy-consuming goods.

- To assist state and local governments in developing their energyefficient procurement programs, the Department of Energy, exercising its authority under EPCA, should provide technical and financial assistance to establish an information clearinghouse. Although the primary function of the clearinghouse should be to gather and disseminate product-specific information, its role could be expanded to include product testing and standards and specifications development.

This report discusses each of these points in detail, describing efforts made by some states and localities to overcome barriers to energy-efficient procurement practices and offering additional ideas for resolving some of 
the problems. This report also briefly examines future opportunities in energy-efficient procurement.

\section{LEGAL FRAMEWORK OF ENERGY-EFFICIENT PROCUREMENT}

The consensus of purchasing officials is that no serious legal barriers are preventing states and localities from applying life cycle costing methodologies or from adopting standards or specifications that incorporate energyefficiency considerations. For proposed strategies involving state-imposed standards for local purchasing, however, of ficials in several states wondered whether such measures would conflict with strong home rule provisions in state constitutions. Most believed that political opposition of local governments to state control of local purchasing would foreclose these strategies long before this legal question had to be resolved.

\section{Lowest Bid Provisions and Life Cycle Costing}

One legal requirement that initially appeared to present an obstacle to life cycle costing was the fairly common statutory provision that contracts be awarded to the lowest bidder. Concerned that these provisions posed a problem, purchasing officials in several states obtained clarifying legal opinions from their state's attorney general. In North Carolina, for example, the attorney general ruled that "the amount and cost of a product's energy consumption is a reasonable and statutorily permissible factor for consideration in determining the most advantageous or lowest responsible bid for award of a contract for purchase." ${ }^{8}$ This opinion reflects the generally accepted interpretation that, as long as prospective bidders are notified that 
life cycle costs will be a bid evaluation criterion, lowest bidder language (which varies from state to state) does not preclude the application of life cycle cost methodologies.

To remove any doubts about whether life cycle costs are a proper bid evaluation criterion, state and local governments could amend their purchasing statutes to include life cycle costs among the factors to be considered in evaluating bids. The American Bar Association's Tentative Draft of a Model Procurement Code ${ }^{9}$ for state and local governments listed "life cycle or total ownership costs" among the criteria that could be used to determine the acceptability of bids. ${ }^{10}$ This preliminary model code provision, which was modified in the final version of the code approved by the American Bar Association," would have permitted, but not required, the consideration of life cycle costs. In contrast, Prince George's County, Maryland, amended its purchasing statute to add life cycle costs to the list of factors the county purchasing agent "shall consider" in detêrmining a bidder's responsibility. ${ }^{12}$ The approach taken by the county ordinance (making consideration of commodities' energy efficiency mandatory) seems preferable to the permissive approach incorporated in the tentative draft of the model code. Although some purchasing officials prefer the flexibility allowed by the permissive approach, others have asserted that a mandate is essential to efforts to initiate energy-efficient procurement programs.

\section{Mandates for Energy-Efficient Procurement}

Affirmative mandates (i.e., state executive orders or statutes) concerning energy-efficient procurement practices serve several purposes. 
First, mandates eliminate any uncertainty that may exist about the legality of such strategies. Second, as catalysts for the adoption of new practices, mandates can make continued adherence to long established practices, such as a tendency to accept bids offering the lowest acquisition price, more difficult. Similarly, mandates can help overcome resistance to new approaches (e.g., life cycle costing to evaluate bids) or strategies (e.g., the purchase of recycled paper). Finally, mandates provide appointed purchasing. officials not only a sword against bureaucratic inertia but also a shield against pressures arising from the of ten highly political nature of the purchasing process. For these and other reasons, almost one-half of the states and several local jurisdictions have executive or legislative mandates concerning energy-efficient procurement.

Executive orders. According to the Council of State Governments, at least eleven states have relied on executive orders to introduce energy efficiency considerations into the purchasing process. To fulfill the EPCA requirement relating to state and local procurement, the governor of Vermont issued an executive order in June $1978 .^{13}$ The order, requires that energy efficiency be considered in the purchase of products and the award of contracts and that purchasing standards take energy efficiency into account. In contrast to this order, which merely commends energy efficiency to purchasing officials, is a more specific order issued by the governor of Idaho in December 1978. This order directs all state agencies "to develop plans and specifications for energy efficiency in the acquisition of commodities purchased and/or acquired by the State, including life-cycle costing for the purchase of all major energy-consuming products." 14 
Statutory mandates. In at least eight states, the legislative rather than the executive branch has taken the initiative to ensure that energy efficiency considerations enter into procurement decisions. The statutes vary considerably in their requirements and scope; there is no outstanding model for other states to adopt. The following paragraphs summarize and analyze these laws:

In 1974 Minnesota became one of the first states to pass legislation concerning energy-efficient procurement. The legislation authorized, but did not require, the director of the energy agency to promulgate rules "to insure that energy use and conservation will be considered in state purchasing and, where appropriate, to require certain minimum energy efficiency standards in purchased products and equipment." ${ }^{15}$ If the director issues any rules, "[n] o state purchasing of equipment or material use shall occur that is not in conformity with these regulations." ${ }^{16}$ After over five years, the energy agency has yet to issue its first rule under this grant of authority. The "low priority" assigned to procurement by the energy agency $^{17}$ suggests that mandates may be ignored if they merely authorize, rather than require, the development of an energy-efficient procurement program.

In 1977 Florida enacted an energy-efficient procurement statute that authorizes the division of purchasing to establish energy efficiency standards for major energy-consuming products and requires the division to use life cycle costing in contracting for products for which standards are established. ${ }^{18}$ To date, the division has applied life cycle costing to evaluate bids for motor vehicles, room air conditioners, water coolers, and ice making machines. 
One of several energy-efficient procurement laws passed during 1978, Ohio's statute requires the Department of Administrative Services to "promulgate rules to ensure that energy efficiency and conservation will be considered in state purchasing." ${ }^{19}$ Under this provision, "[m] inimum energy efficiency standards on purchased products and equipment shall be required . . .," and "[1] ife-cycle costing of energy consuming equipment and components shall be applied to competitive bidding where appropriate . . ." The law also authorizes the department to require bidders to furnish information on the energy efficiency or energy usage of their products. ${ }^{20}$

Hampered by a lack of appropriations, the Ohio department did not begin work on the required regulations until early 1979. Even after the regulations are issued, they may have only a limited impact because the department handles only 50 percent of the state's procurement and has no authority to establish procurement policy for other state agencies. ${ }^{21}$

The Arizona legislature created a state purchasing review board in 1978. The legislation requires the board to "adopt rules and regulations establishing minimum standards for the procurement of energy consumptive products by [the] state and [its] political subdivisions. ..." ${ }^{22}$ The standards are to "be based upon considerations of energy conservation and of life cycle cost. . . ."23 The board began its work in early 1979.

Kentucky amended its purchasing statute in 1978 to provide an explicit mandate to the purchasing division concerning energy-efficient procurement.

The executive department for finance and administration shall have control and supervision over all purchases of energy consuming equipment, supplies and related equipment purchased or acquired by any agency of the state ... and shall designate by regulation the manner in which an energy 
consuming item will be purchased so as to promote energy conservation and acquisition of energy efficient products. 24

Pursuant to this grant of authority, the division of purchases has issued a policy and procedure memorandum on energy conservation in procurement. ${ }^{25}$ Agencies are required to use life cycle cost techniques or other energy saving methods to purchase appliances, equipment, machinery and related products that consume energy. To assist agencies in carrying out this responsibility, the division of purchases has prepared life cycle cost formulae for several products. (Some of the formulae are reproduced in the Technical Appendix to this report.)

Although the Kentucky statute appears to give the division of purchases comprehensive authority covering "all purchases" by "any agency," purchases of energy-consuming items by delegated purchasing authorities (mainly state universities) and purchases of such items where the total estimated cost of the purchase is less than $\$ 500$ are not subject to the division's control or supervision. The division is currently trying to close this loophole in its energy-efficient procurement program.

Unlike the Ohio, Arizona, and Kentucky laws, which vest authority and impose responsibility for an energy-efficient procurement program on a specific state agency, Hawaii legislation declares a broad policy without making any particular agency responsible for its implementation. Under Hawaii Act 134 (1978), "[t] he procurement practices of the State and its counties shall include energy efficiency standards and policies, including life cycle costing." 26 Subsequent provisions of the statute translate this general policy statement into more specific requirements. For example, purchasers are required to consider using life cycle cost methods to purchase "those 
classes of items for which nationally recognized energy efficiency data have been developed." The law does not preclude the application of life cycle costing to other products, but Hawaii is awaiting "the development of national standards for life-cycle costing" before extending its energyefficient procurement program beyond automobiles, air conditioners and watt-saving flourescent lamps. ${ }^{27}$

While the Hawaii law on its face permits state and local purchasing officials to expand their programs to cover more than the minimum requirements, a Tennessee statute severely limits state and local initiative in energy-efficient procurement. Chapter 655 (1978) states that "[o] nly those products which have received a life cycle cost and/or energy efficiency standard by the federal government shall be purchased according to life cycle cost and/or energy efficiency standard." 28 This statute ignores the accomplishments of several states in developing life cycle formulae for various products and prohibits Tennessee and its cities and counties from taking advantage of this work. In this respect, the statute, ironically enough, constitutes a legal barrier to energy-efficient procurement.

In addition to this serious shortcoming, the Tennessee law has two other noteworthy features. Like the Hawaii statute, the Tennessee law applies to the state's political subdivisions. The requirement of the Tennessee law, however, is much more specific. In Tennessee, "every political subdivision shall adopt and incorporate in its procurement policies energy efficiency standards and life cycle costing employed by the state in its procurement policies." ${ }^{29}$ Unlike any other energy-efficient procurement statute, the Tennessee law includes a provision under which a seller of a commodity can sue to have a court declare executory contracts for the 
purchase of a commodity by a political subdivision void if the suing party can supply a commodity with a better energy efficiency rating and lower life cycle cost. ${ }^{30}$ The current language of this provision allows any seller of the commodity, even one who did not bid on the contract, to challenge the contract. Because this result seems contrary to rational purchasing policy and could result in administrative nightmares, any similar provisions in state energy-efficient procurement legislation should limit the right to sue to sellers who actually bid on a contract.

Despite its flaws, the Tennessee statute establishes a stronger commitment to energy-efficient procurement than does legislation passed in New Jersey in 1978. New Jersey amended its basic purchasing statute to add a provision that specifications and invitations for bids "shall, wherever practicable, include such factors as life-cycle costs, sliding percentage preference scales, or other similar analysis as shall be deemed effective by the Director of the Division of Purchase and Property." ${ }^{31}$ According to a state purchasing official, this provision has not had a major impact on New Jersey's procurement practices.

Mandates concerning buildings, automobiles, and recycled paper. In addition to the eight states that have passed generally applicable energyefficient procurement statutes, a significant number of states have enacted energy-efficient procurement laws that cover certain commodities (automobiles and recycled paper, for example) or state buildings. At least twelve states have statutes requiring life cycle cost analyses of design alternatives to be performed prior to the construction of state buildings. ${ }^{32}$ Some of these laws also require analyses to be undertaken prior to major renovations of state buildings. An illustration demonstrates the need for statutes of this 
type. Life cycle costing of alternative building designs seems sensible and non-controversial, yet attempts to adopt this technique informally have met resistance in Virginia. ${ }^{33}$ Even though selecting building designs on a life cycle cost basis would save the state money over the long run, officials responsible for state buildings are reluctant to seek or spend appropriations to cover any increase in initial building costs that might result from this strategy. The hesitation may stem from a fear of the repercussions of increasing government spending or it may simply reflect a resistance to change. In either case, the enactment of energy-efficient procurement mandates, covering not only buildings but other commodities as well, may be necessary to persuade many purchasing officials or their superiors of the wisdom of spending money to save money (and energy).

While a number of states are using life cycle cost methodologies to buy automobiles for state fleets, a few states have legislated purchasing requirements based on the federal fuel economy standards imposed by EPCA. Ohio, for example, requires that all passenger vehicles acquired in a fiscal year achieve a specific fleet average fuel economy. ${ }^{34}$ Unlike a life cycle costing approach under which a state could conceivably consider the least efficient models and buy the most efficient of those, the purchasing strategy adopted by Ohio establishes a minimum efficiency standard. Combining a requirement for life cycle cost analysis with a minimum standard could upgrade the energy efficiency level of purchased commodities. Under this approach, a state, in most' cases, would buy the most efficient model of those that meet the minimum standard.

In contrast to the willingness of states and localities to purchase energy-efficient automobiles, considerable resistance has developed to 
another energy-efficient procurement practice: the purchase of commodities, primarily paper, made from recycled materials. ${ }^{35}$ In 1975 Maine passed legislation that created a preference for goods made from recycled materials if the goods are "equal in quality" and "competitively priced" when compared to goods not containing recycled materials. ${ }^{36}$ These requirements, however, constitute the primary barriers to the implementation of this procurement strategy. In many states, for example, demand for recycled paper is.low because office workers dislike its off-white color and lack of "snap." A more significant reason for the scarcity of recycled paper purchasing programs is that many purchasing officials have found that recycled paper of ten costs more than regular paper. ${ }^{37}$ Maryland, however, which has pioneered the purchase of recycled paper, has actually saved money buying recycled paper.

In 1977 Maryland enacted legislation requiring the state purchasing agent to buy a certain percentage of recycled paper. ${ }^{38}$ For 1978,5 percent of the paper purchased had to be recycled paper. The percentage requirement increases to 25 percent for 1981 and 40 percent for 1985 . The commitment to purchasing recycled paper is not qualified by a requirement that recycled paper be competitively priced, and even if it were, Maryland's program would not be hampered. According to the Maryland Energy Policy Office, buying recycled paper has saved the state almost $\$ 16,000$ since the program began in fiscal year $1978 .^{39}$ The recycled bond paper that Maryland buys costs the state 7 to 10 cents less per ream than \#l bond paper. Energy savings attributable to the purchase of recycled paper have amounted to 15 billion Btus or enough electricity for about 168 homes for a year. ${ }^{40}$ Anne Arundel, Howard and Prince George's counties, the Town of St. Michaels and 
the City of Annapolis have purchased recycled paper from the state warehouse. Anne Arundel County passed an ordinance in 1978 requiring purchase of a certain percentage of recycled paper in the 1980 and 1981 fiscal years. $^{41}$

Recognizing that Maryland's circumstances (access to good quality, low priced recycled paper) may be unique, the Maryland Energy Policy Office has prepared a draft model recycled paper law for other state and local governments interested in a recycled paper purchasing program. ${ }^{42}$ To overcome the economic barrier presented by the generally higher cost of recycled paper, the draft model law would grant a percentage price preference to recycled paper. The purchasing department is required to purchase "the maximum amount of recycled paper practicable" with the proviso that "recycled paper shall be no more than ten percent more expensive than virgin paper." In this respect, Maryland's draft model statute is more generous than California's recycled paper law.

In 1977 California passed legislation requiring the Department of General Services to "give preference to the suppliers of recycled paper if the bids of such suppliers do not exceed by more than 5 percent the lowest bid or price quoted by suppliers of fering nonrecycled paper products." ${ }^{43}$ The statute also directs the department to establish a paper recycling program. Revenues from the sale of paper collected by this program go first to cover program costs and then "to reduce increased charges for recycled paper furnished to state agencies by the department due to the preference." ${ }^{44}$

A decision on whether to purchase recycled paper requires state and local governments to balance several factors. Unlike many energy-efficient products, which may cost more initially yet save money over the long run, 
recycled paper may cost more initially but not yield any direct savings the way efficient automobiles would. A program like California's to recycle and sell wastepaper could be established to reduce the additional cost of the

recycled paper. ${ }^{45}$ Despite the higher cost, there are sound reasons for establishing recycled paper purchasing programs. In addition to the resource conservation benefits of buying recycled paper, reusing wastepaper eases the burden paper places on the solid waste system. Without a legislative mandate concerning recycled paper, however, it is doubtful that many states and localities will buy recycled paper to take advantage of these benefits.

\section{INSTITUTIONAL FRAMEWORK OF ENERGY-EFFICIENT PROCUREMENT}

\section{Decentralized Purchasing Systems}

One of the major institutional barriers to the implementation of energy-efficient procurement practices in state purchasing is the existence in some states of decentralized purchasing systems. Rather than convincing only one office of the merits of energy-efficient procurement practices, advocates of life cycle costing and other strategies must educate and convert the numerous autonomous purchasing officials operating out of separate state agencies in a decentralized system. Without central control over procurement activities, ensuring that energy-efficient procurement practices are actually implemented may prove difficult, even where, as in Hawaii, these practices are statutorily mandated. 46

In a. 1975 study of state and local government procurement, the Council of State Governments strongly recommended the establishment of centralized purchasing systems for reasons unrelated to energy conser- 
vation. 47 Centralized purchasing facilitates volume buying, thus allowing governments to purchase commodities at economical prices. According to the Council, centralized purchasing should also guard against favoritism and fraud in the purchasing process. Most importantly, a centralized purchasing system increases the chances that basic policies and standard procedures will be implemented.

If all these advantages have proven insufficient to persuade states with decentralized purchasing systems to overcome the political forces opposed to centralization, it seems unlikely that the addition of energy conservation to the equation will alter the outcome. Several options exist, however, through which these states could promote energy-efficient procurement practices.

Achieving energy-efficient procurement in decentralized purchasing systems. Instead of reorganizing the entire state purchasing process, a state could centralize only the purchasing of major energy-consuming items. This approach was suggested by the State of Hawaii Purchasing and Supply Division as one way to overcome the handicap of decentralized purchasing to energy-efficient procurement. ${ }^{48}$

Because a proposal to remove actual purchasing power and functions from individual agencies may generate substantial political opposition, less drastic approaches should be considered. One alternative is to leave the actual purchasing of energy-consuming products to the separate agencies, but to require that they adhere to energy-efficient procurement regulations issued by the purchasing division. Statutory language to accomplish this alternative could draw upon the Kentucky statute described above. The statute could give the purchasing division "supervision over all purchases of 
energy consuming equipment, supplies and related equipment purchased or acquired by any agency of the state." The statute could authorize the division to "designate by regulation the manner in which an energy consuming item will be purchased so as to promote energy conservation and acquisition of energy efficient products." All state agencies would be directed to purchase in accordance with these regulations. If a legislature chooses this alternative, it should also provide the purchasing division sufficient staff and funds to carry out the mandate.

Another approach to increase the use of energy-efficient procurement practices in states with decentralized purchasing systems is to issue an executive order. In Idaho, for example, an executive order directs all state agencies to "develop plans and specifications for energy efficiency in the acquisition of commodities purchased and/or acquired by the State." ${ }^{49}$ Any executive order of this type would designate the purchasing division or other appropriate agency to oversee the agencies' implementation of the mandate. The agency chosen for the overseer's role should receive the appropriations necessary to fulfill its duties.

The State Role In Energy-Efficient Procurement by Local Governments

As an institutional barrier to energy-efficient procurement, decentralized purchasing systems are a problem in only a few states. A more serious problem is the progress of energy-efficient procurement at the local level. Responses received from the Institute's inquiries to the purchasing officials of large cities and counties seem to suggest that beyond limited use of life cycle costing, local governments have done relatively little to implement energy-efficient procurement measures. ${ }^{50}$ One reason for this is 
that even large cities and counties do not purchase many energy-consuming items in sufficient quantities to justify devoting scarce resources (money and manpower) to developing extensive energy-efficient procurement programs.

Recognizing the difficulties that cities and counties face, most states have included in their energy conservation plans elements designed to assist their political subdivisions to establish energy-efficient procurement programs. The most popular elements include making energy efficiency data, standards and specifications available to local purchasing officials and educating these officials about energy-efficient procurement. Some states also encourage local governments to exercise the option of purchasing major energy-consuming items through the state.

It is too early to know whether these efforts will succeed in overcoming the obstacles to energy-efficient procurement at the local level. Of the various programs, promoting increased cooperative purchasing for energy-efficient commodities should receive top priority. If, however, encouragement, education, and information sharing fail to advance energyefficient procurement at the local level, states have several other options to consider.

In states that have centralized purchasing systems or that institute centralized purchasing solely for major energy-consuming items, local governments could be more strongly encouraged or even required to purchase these items through the state. Aside from ensuring that local governments would be supplied with energy-efficient products, this arrangement would concentrate the governments' purchasing power. Not only could volume buying bring lower prices, but it could also provide manufacturers an 
incentive to improve the energy efficiency of their products. Several factors, however, make the enactment of legislation to transfer purchasing of major energy-consuming items from the local to the state level unlikely.

Strong home rule provisions in some state constitutions may bar legislation establishing this type of state control of local purchasing. Even where this legal obstacle does not exist, other objections to the proposal will probably lead to its rejection. State purchasing officials may particularly oppose the idea if they are expected to assume the burden without any increase in personnel or budget. Local governments and purchasing officials will undoubtedly oppose any proposal that would significantly infringe upon the power of local governments. Furthermore, those local purchasing officials who have developed fairly advanced energy-efficient procurement programs will object, with good cause, to having their programs supplanted by a less sophisticated or comprehensive state program. Absolute state control over local purchasing of energy-consuming commodities, therefore, may be neither feasible politically nor desirable from a practical standpoint. 51

States have still other options that may achieve the goal of energyefficient procurement by local governments without generating as many objections. Tennessee's energy-efficient procurement legislation offers one such approach. The Tennessee law requires "every political subdivision [to] adopt and incorporate in its procurement policies energy efficiency standards and life cycle costing employed by the state in its procurement policies." 52 This provision leaves the basic purchasing power of local governments undisturbed while establishing an energy-efficient procurement program in every city, town, and county in a state. By not placing any 
limits, as the Tennessee law unfortunately does, ${ }^{53}$ on the products that may be purchased according to life cycle costing or energy efficiency standards and by allowing local governments to adopt standards more stringent than the state's, as the Tennessee law wisely does, ${ }^{54}$ a state could provide local purchasing officials the freedom to reach beyond the basic program. Drafted with these provisions, the law would not stifle local programs that are more advanced than the state program.

The California recycled paper law incorporates the approach of coupling a minimum requirement with an option for local initiative. The law requires "all local public agencies [to] purchase recycled paper and paper products instead of unrecycled paper or paper products whenever available at no more than the total cost of unrecycled paper or paper products." 55 The statute authorizes local agencies to give a 5 percent price preference, which state agencies must give, to suppliers of recycled paper or paper products. $^{56}$ This law permits local agencies to pursue this energy-saving procurement strategy aggressively, but does not require them to do so if they do not want to incur the additional expense.

Arizona's statute suggests yet another approach to increasing energyefficient procurement by local governments. The Arizona purchasing review board, required to establish "minimum standards for the procurement of energy consumptive products" by the state and its political subdivisions, consists of fif teen members, three of whom must be representatives of local purchasing offices. ${ }^{57}$ At the time of this writing, six of the board's members are local purchasing officials. Involvement of local purchasing officials in the process of developing minimum standards may defuse local opposition to energy-efficient procurement strategies. 
Finally, states can promote energy-efficient procurement at the local level by encouraging local governments to participate in joint or cooperative purchasing arrangements. Nearly all of the states allow local governments to "piggy-back" on state contracts. ${ }^{58}$ This practice should be encouraged particularly for contracts for energy-consuming products. In addition to increased purchasing through the state, local governments could join together to purchase energy-consuming items. Several local governments pooling their resources could write energy efficiency standards and specifications that would be impractical for any one to develop alone. The higher volume of the combined requirements of several local governments should make suppliers more willing to furnish the energy-efficient commodities sought. It is even conceivable that sufficient demand could be created by joint or cooperative purchasing arrangements to spur manufacturers to modify products specifically to meet more stringent energy efficiency standards.

Statutory authorization of joint or cooperative purchasing may be necessary to eliminate any doubts about the legality of the practice. The American Bar Association-approved Model Procurement Code for state and local governments includes a provision authorizing cooperative purchasing arrangements between state and local governments and among local governments. $^{59}$ In some states cooperative purchasing may be allowed under existing statutes. In Maine, for example, the Interlocal Cooperation Act ${ }^{60}$ permits local governments to purchase jointly. 


\section{THE INFORMATION GAP}

During the Institute's search for legal or institutional factors that have impeded implementation of energy-efficient procurement, purchasing officials identified two unmet needs as the most significant barriers to energy-efficient procurement. First, officials claimed that their efforts are hampered by the lack of credible product-specific, technical information for many energy-consuming products. Officials want more test results, energy efficiency standards and specifications and life cycle cost formulae. More extensive product information is needed not only to enable procurement officers to incorporate energy efficiency considerations into purchasing decisions, but also to maintain the integrity of the procurement process. For example, competition may be limited if purchasing agencies request energy efficiency information in invitations for bids, thereby excluding potential bidders who cannot furnish the data. 61 Too. of ten the only available energy efficiency information has been generated by manufacturers or trade associations. Purchasing of ficials who award contracts based on this data risk having the awards challenged, by disappointed bidders. 62 . The second barrier confronting purchasing officials is insufficient resources (money, people and expertise) to develop product information for all of the energy-consuming items they purchase. Even if the resources existed, it would make no sense for states to duplicate each other's efforts. Both of these problems can be met by an organization such as an information clearinghouse, established to disseminate product-specific information, to test products, and to develop energy efficiency standards and specifications.

Some purchasing officials prefer that the federal government take the initiative and shoulder the burden of developing and disseminating 
product-specific information. At the present time, however, no federal entity seems capable of fulfilling both functions. The Center for Consumer Product Technology at the National Bureau of Standards is developing test methodologies to quantify the energy use of various products. The Center has developed some of the methodologies used in the appliance efficiency and labelling program established by the Energy Policy and Conservation Act of 1975 and the National Energy Conservation Policy Act of $1978 .{ }^{63}$ The Center's test methodologies are used by the Bureau's Experimental Technology Incentives Program to develop energy-efficient product specifications. The Bureau, however, is not equipped to serve as an information clearinghouse.

Presently, the Federal Supply Service (FSS), part of the General Services Administration whose primary mandate is to supply the federal government, responds on a limited basis to state requests for productspecific information. The agency's activities related to energy-efficient procurement include training of purchasing of ficials and developing product specifications. The FSS holds workshops on life cycle costing for federal, state and local purchasing officials. The FSS also selects products for energy efficiency testing and develops product specifications based on these tests. When funds are available, the FSS publishes case studies on products it has tested; even if a case study is not prepared, the FSS tries to provide product information to state and local governments on request. Yet without additional staff and funds, the FSS cannot serve as a centralized clearinghouse for product-specific information.

The federal orientation of the FSS program suggests that a clearinghouse established under the aegis of the National Association of 
State Purchasing Officials (NASPO) or the National Institute of Governmental Purchasing (NIGP) might be more sensitive to the needs of state and local government officials. Ideally, the clearinghouse would function as a liaison between the federal government (the National Bureau of Standards and the FSS) and state and local purchasing of ficials and among these officials themselves, with its primary function being to gather and disseminate product-specific information. The clearinghouse could evaluate the data and specifications developed by government purchasing officials, trade associations and product manufacturers in order to enhance the reliability of its information. With sufficient funding, the clearinghouse could even test products and prepare standards and specifications.

One previous attempt to establish a clearinghouse to assist energyefficient procurement efforts at the state and local level floundered. A proposed cooperative arrangement between the National Bureau of Standards and NASPO to establish a Public Procurement Research Foundation never got of $f$ the drawing board.

The U.S. Department of Energy should seriously consider supporting a clearinghouse with federal financial and technical assistance. Closing the information gap would do more to advance energy-efficient state and local procurement than any other action the federal government could take.

\section{FUTURE OPPORTUNITIES IN ENERGY-EFFICIENT PROCUREMENT}

In a 1977 book, Government Procurement and Operations, ${ }^{64}$ Ivan J. Tether analyzed a variety of energy-efficient procurement strategies that states and localities can implement. In addition to life cycle costing and 
energy efficiency standards and specifications already used by many state and local purchasing offices, the book examines value incentive contract clauses, the purchase of commodities on the basis of the energy used in their manufacture, the purchase of products made from recovered materials and the use of contract leverage to induce government contractors to conserve energy. The information collected by the Institute on state and local energy-efficient procurement programs revealed that very few purchasing offices currently use or are even considering using any of these strategies.

The Illinois State Office of Procurement investigated the feasibility of value incentive contract provisions for certain types of purchasing as part of the state's energy conservation plan. After an initial review, the office concluded that value incentive clauses have "very little, if any, application in State purchasing" and that, as a result, development of the strategy should be assigned a low priority. ${ }^{65}$ The California Department of General Services found that "[v] alue incentive clauses are difficult or impossible to affect in competitive bidding and are presently outside the State Procurement Code." ${ }^{66}$ No state reported using value incentive clauses specifically to promote energy conservation. 67

Despite the difficulties involved in determining the energy inputs of commodities, ${ }^{68}$ several states have implemented programs to identify and to buy goods that require less energy to manufacture. The Florida Division of Purchasing recently completed a screening program to determine which products have the greatest energy-saving potential. ${ }^{69}$ Wyoming is currently purchasing natural (unbleached) paper towels because their manufacture requires only 60 percent of the energy needed to produce bleached paper towels. 
Programs to procure products made from recovered materials exist in several states and localities. ${ }^{70}$ State and local programs for purchasing recycled paper are discussed in an earlier section of this report. Recycled vehicle tires (retreads or recaps) are another commodity that governments could purchase to save energy, since recapping an old tire requires only onethird as much energy as manufacturing a new tire. Because of the energy and money savings associated with retreaded tires, Arizona's state energy board has recommended that government agencies increase their use of recapped tires. ${ }^{71}$

The purchase of products made from recovered materials should receive additional impetus as the U.S. Environmental Protection Agency (EPA) fulfills its duties under $\$ 6002$ of the federal Resource Conservation and Recovery Act of $1976 .^{72}$ Although the requirements imposed on procuring agencies by this section are not expected to have a direct major impact on state and local procurement, ${ }^{73}$ the guidelines that EPA must issue concerning procurement of items containing recovered materials should help states and localities to implement this energy conservation strategy. ${ }^{74} \mathrm{By}$ the end of 1979 EPA hopes to begin formal rulemaking proceedings, in which interested state and local governments could participate, to develop guidelines for paper products, construction materials and the use of fly ash in cement and concrete. ${ }^{75}$

No states reported actually using contract leverage to encourage government contractors to conserve energy (e.g., qualification and debarment of bidders based on the energy efficiency of their operations). The California procurement law, however, directs the Department of General 
Services to "require the persons with whom it contracts to use, to the maximum extent economically feasible in the performance of contract work, recycled paper." ${ }^{76}$

\section{CONCLUSION}

Today energy-efficient procurement programs in state and local governments are caught in conflicting cross currents. On the one hand, the tax revolt signalled by Proposition 13 and its progeny make government officials reluctant to spend extra money now to purchase more energyefficient products, even though savings over the long run will exceed the additional initial investment. On the other hand, the disruptions in the world oil market, heightened by the political turmoil in Iran, have accelerated the upward spiral of energy, prices. Under these circumstances, purchasing officials should renew their efforts to implement energy-efficient procurement practices in order to realize the dollar savings that are multiplied as energy costs increase.

If purchasing officials or their superiors are slow to seize the initiative, states should enact legislation to mandate energy-efficient procurement practices. The federal government can assist the states and localities in eliminating the most significant barrier to energy-efficient procurement-the information gap-by supporting the creation of a clearinghouse to disseminate product-specific information on energy-consuming commodities. 


\section{NOTES}

1. Pub. L. No. 94-163.

2. Pub. L. No $94-163$, $\$ \$ 361-366 ; 42$ U.S.C. $\$ \$ 6321-6326$.

3. Pub. L. No. 94-163, $\$ 362(c)(3) ; 42$ U.S.C. $\$ 6322(c)(3)$.

4. 10 C.F.R $\$ 420.35(c)(2)$ (1978). The Department of Energy revised the regulations governing the state energy conservation plans program, but this procurement provision was not changed. 10 C.F.R. $\$ 420.7(\mathrm{c})(2)$ at 44 Fed. Reg 20061 (April 4, 1979).

5. The reasons for the protracted infancy of the state procurement programs vary from state to state. Among the explanations offered by state procurement and energy of ficials are apathy arising from a belief that an energy problem does not exist, resistance to changing established procurement practices to incorporate energy efficiency considerations, delays in funding and staffing state energy-efficient procurement programs, and a lack of technical assistance from the federal government.

6. The Institute mailed two letters to each state's procurement department and energy office and to nearly 100 cities and counties. The first letter described the purpose of the project and requested assistance in identifying problem areas hampering the development of energyefficient procurement programs. The second letter identified the issues we had targeted and sought the of ficials' suggestions for solving these problems.

In response to our letters and follow-up telephone calls to several states and localities, we received information from the procurement departments in 58 percent of the states, from the energy offices in $\mathbf{7 2}$ percent of the states, and from purchasing officials in 8 percent of the cities and counties originally contacted.

7. The Council of State Governments, as a subcontractor to the National Governors' Association and the National Association of State Purchasing Officials, in a project for the U.S. Department of Energy, examined the structure, content and activities. of each state's energyefficient procurement program for the ultimate purpose of designing " $a$ national administrative strategy to achieve energy conservation through procurement." For information on this project, contact

James F. Runke or Steven L. Elstein

Council of State Governments

P.O. Box 11910

Iron Works Pike

Lexington, Kentucky 40578

(606) 252-2291

8. Attorney General's Opinion to North Carolina Department of Commerce, Energy Division (March 30, 1977). See also Attorney General's Opinion No. 7648 to the Oregon Department of General Services, Purchasing Division (July 13, 1978).

9. In February 1979 the American Bar Association's House of Delegates approved the final draft of a Model Procurement Code for state and local governments. American Bar Association, The Model Procurement Code for State and Local Governments (February 1979). A joint project of the ABA's Sections of Public Contract Law and Urban, State and Local Government Law, the code was drafted over a period of five years with extensive input from procurement professionals and the participation of the project's Pilot Jurisdictions. Pilot states and cities have included Kentucky; Tennessee; New Mexico; Louisiana; Utah; Louisville, Kentucky; Knoxville, Tennessee; Baltimore, Maryland; and San Diego, California. Kentucky and Knoxville have adopted code-based procurement legislation. For further information concerning the code, contact 
Model Procurement Code Project

$1700 \mathrm{~K}$ Street, N.W.

Suite 601

Washington, D.C. 20006

(202) 331-0133

or

Governmental Relations Office

American Bar Association

1800 M Street, N.W.

Washington, D.C. 20036

10. American Bar Association, A Model Procurement Code for State and Local Governments, Tentative Draft (July 1978) \$ 3-202(6). This provision on bid evaluation stated, in pertinent part: "Bids shall be evaluated based on the requirements set forth in the Invitation for Bids, which may include criteria to determine acceptability such as inspection, testing, quality, workmanship, delivery, and suitability for a particular purpose, and criteria affecting price such as life cycle or total ownership costs."

11. The final version of the model code provision on bid acceptance and evaluation draws a distinction between factors affecting an item's acceptability and those affecting the bid price such as life cycle costs. The "criteria affecting price" phrase in the tentative draft is deleted from the final version and replaced by the following sentence: "Those criteria that will affect the bid price and be considered in evaluation for award shall be objectively measurable, such as discounts, transportation costs, and total or life cycle costs." Model Procurement Code, supra note $9, \$ 3-202(5)$. Commentary on this code provision states that "[t] he bid evaluation may take in to account not only acquisition costs of supplies, but the cost of their ownership which relates to the quality of the product, including life cycle factors such as maintainability and reliability."

According to the staff of the Model Procurement Code project, the approach of the final version incorporates the flexibility sought by purchasing professionals for determining how and when life cycle factors can be most appropriately considered.

12. Prince George's County (Maryland) Code $\$ 10-160(1)(i)$.

13. Vermont, Executive Order 18 (June 28, 1978).

14. Idaho, Executive Order 78-6 (December 28, 1978). Maine also has an executive order directing the Bureau of Purchases to use life cycle costing whenever feasible, especially in energyconsuming purchases.

15. Minnesota Chapter 307 S,L. 1974, \$12, codified at Minn. Stat. $\$ 116$ H.12(5).

16. Id.

17. Telephone conversation with Susan Stewart, Minnesota Energy Agency (April 9, 1979). According to Ms. Stewart, Minnesota places a greater emphasis on procurement in the amended state energy conservation plan it has filed with the Department of Energy.

18. Florida Chapter 77-316 S.L. 1977, \$2, codified at Fla. Stat. $\$ 287.083$. This law also amends Fla. Stat. $\$ 287.032$ to add "the conservation of energy" to the enumerated purposes of the Division of Purchasing.

19. Ohio Amended Substitute House Bill No. 419, $\$ 1$, codified at Ohio Rev. Code $\$ 123.011$ (D).

20. H.B. $419 \$ 1$, codified at Ohio Rev. Code $\$ 125.09$.

21. Letter from Thomas P. Ryan, Deputy Director, Ohio Department of Energy (February 16, 1979). Later this year, the state will issue a Request for Proposals seeking a consulting firm to study the problems created by the ambiguous statute. Telephone conversation with John Kiger, Administrator of State Purchasing, Ohio Department of Administrative Services (April 5, 1979).

22. Arizona Chapter 180 S.L, 1978, \$ 2, codified at Ariz. Rev. Stat. \$ 41-568. 
23. Id.

24. Kentucky Chapter 260 S.L. 1978, codified at Ky. Rev. Stat. $\$$ 45.360(13). Kentucky also enacted procurement legislation in 1978 based on a draft version of the American Bar Association's model procurement code. Ky. Rev. Stat. \$\$ 45A.005-45A.990. The Kentucky Model Procurement Code supplements, but does not supersede, Kentucky's purchasing statute of which $\$ 45.360(13)$ is a part. Telephone conversation with Harold M. Staton, Division of Purchases, Kentucky Department for Finance and Administration (April 12, 1979).

25. Commonwealth of. Kentucky, Executive Department for Finance and Administration, Management Manual, Policy BO-116-10-00 and Procedure BO-116-10-01.

26. Hawaii Act 134 S.L. 1978, $\$ 2$, codified in Haw. Rev. Stat. $\$ 103$.

27. Id.

28. Tennessee Chapter 655 S.L. $1978, \$ 4$.

29. Id., $\$ 7$.

30. Id., $\$ 8$.

Section 8. (a) Executory contracts for the purchase of commodities by a political subdivision included in this Act shall be voidable by the circuit courts upon the bringing of an action by an aggrieved party.

(b) The court may void the contract upon the showing by the aggrieved party that:

(1) the party is a seller of the commodity;

(2) the party is doing business in the state;

(3) the commodity to be sold has an energy efficiency rating and life cycle cost lower than the commodity contracted for by the purchaser;

(4) the purchaser is a political subdivision, and the standard for the commodity has been adopted for one (1) year by the board of standards and has not been incorporated or adopted by the political subdivision; and

(5) the aggrieved party is ready, willing and able, without any other legal constraints, to sell the commodity to the purchaser.

31. New Jersey Assembly Bill No. 153 (1978), codified at N.J. Rev. Stat. $\$ 54: 34-12(a)$.

32. Florida Chapter 74-187 S.L. 1974, North Carolina Chapter 434 S.L. 1975, Colorado House Bill 1206 (1976), Massachusetts Chapter 433 S.L. 1976, Connecticut Public Act No. 77-597 S.L. 1977, Maine Chapter 320 S.L. 1977, Rhode Island Chepter 199 S.L. 1977, Wyoming Chapter 121 S.L. 1977, Maryland Chapter 597 S.L. 1978, Mississippi Senate Bill No. 2379 (1978), New Jersey Assembly Bill No. 562 (1978) and Ohio Amended Substitute House Bill 419 (1978). See also Model Procurement Code, supra note 9, art. 5 .

33. Telephone conversation with B. Boyd Johnson, Chief, Intergovernmental Branch, Division of Energy, Virginia State Office of Emergency and Energy Services (February 23, 1979).

34. Ohio Rev. Code $\$ 123.011(\mathrm{E})$.

35. The federal Resource Conservation and Recovery Act of 1976 (RCRA) requires procuring agencies, which include state and local agencies using appropriated federal funds for procurement, to "procure items composed of the highest percentage of recovered materials practicable consistent with maintaining a satisfactory level of competition." 42 U.S.C. $\$$ 6962(c) and 42 U.S.C. $\$ 6903(17)$. The implications of RCRA for state and local procurement are discussed more fully in the final section of this paper.

36. Me. Rev. Stat. tit. 5, \$1812.

37. Two closely related factors explain why paper made from recycled fibers generally costs more than paper made from virgin fibers. First, it costs more to make comparable quality 
paper suitable for office use from recycled fibers because the costs of processing the scrap paper (de-inking and bleaching it, removing staples, etc.) are higher than the costs of processing virgin raw materials. Second, and perhaps more important, the inability of producers of recycled paper to achieve economies of scale results in higher production costs that drive up the prices of recycled paper.

38. Md. Ann. Code art. 41, \$231-IA.

39. Maryland Energy Policy Office, Recycled Paper Fact Sheets (November 16, 1978 and February 7, 1979). For information on the Maryland programs, contact

\author{
Richard Keller \\ Energy Policy Office \\ Department of Natural Resources \\ 1302302 State Office Building \\ $301 \mathrm{~W}$. Preston Street \\ Baltimore, Maryland 21201 \\ (301) 383-6810
}

40. Id.

41. Anne Arundel County, Maryland Bill No. 77-78 (1978).

42. The Recycled Paper Purchasing Act of 1979 is available from the Maryland Energy Policy Office. (See note 39 for the address of the office.)

43. Cal. Gov't Code S 14784.3.

44. Cal. Gov't Code $\$ 14785$.

45. Maryland expects to begin collecting of fice wastepaper for recycling in 1979. Three Maryland counties (Howard, Kent and Prince George's) already have wastepaper recycling programs. For more information about the Maryland program, contact the Maryland Energy Policy Office at the address given in note 39.

46. Letter from Earl B. Dedell, Chief, Purchasing and Supply Division, State of Hawaii Department of Accounting and General Services (February 2 l, 1979).

47. The Council of State Governments, State and Local Government Purchasing (Lexington, Ky: The Council of State Governments, 1975) Chapter 3. See also Model Procurement Code, supra note $9, \$ 2-301$ (code provision establishing centralized purchasing).

48. See note 36 supra. Cf. Model Procurement Code, supra note 9,5 2-303.

49. Idaho, Executive Order 78-6 (December 28, 1978).

50. The local governments most frequently mentioned as having advanced energy-efficient procurement progams were Baltimore, Md.; Chicago, Ill.; Maricopa County, Arizona; and Philadelphia, $\mathrm{Pa}$.

51. One practical limitation on state control of local purchasing are variances in usages between a state and its political subdivisions.

52. Tennessee Chapter 655 S.L. 1978, \$7.

53. Id., \$ 7. See the discussion of this aspect of the Tennessee law at p. 12.

54. Id., $\$ 11$.

55. Cal. Gov't Code $\$ 14785.1$.

56. Id.

57. Ariz. Rev. Stat. \$ 41-567.

58. According to the Ohio Department of Administrative Services, local governments in Ohio 
authorizes the department to purchase for state departments, offices and institutions. Ohio Rev. Code $\$ 125.02$. Telephone conversation with John Kiger, Administrator of State Purchasing, Ohio, Department of Administrative Services (April 5, 1 979). Cf. Model Procurement Code, supra note 9, \$ 10-201.

59. Model Procurement Code, supra note 9, $\$ 10-201$. This provision even authorizes cooperative purchasing arrangements between procurement units in different states.

60. Me. Rev. Stat. tit. 30, \$\$ 1951-1958.

61. Letter from E. R. Roon, State Purchasing Director, Division of Purchasing, Colorado Department of Administration (February 13, 1979) and letter from Harold M. Staton, Division of Purchases, Kentucky Department for Finance and Administration (February 14, 1979).

62. Letter from Hugh M. Carleton, Director of Purchasing, Louisiana Division of Administration (February 21, 1979) and telephone conversation with John Kiger, Administrator of State Purchasing, Ohio Department of Administrative Services (April 5, 1979).

63. The appendices to 10 C.F.R. Part 430 (1978) set forth uniform test methods for measuring the energy consumption of eleven appliances.

64. Ivan J. Tether, Government Procurement and Operations (Cambridge, Mass.: Ballinger Publishing Co., 1977).

65. Letter from Robert M. Lohrenz, Supervisor, Standards and Specifications, Office of Procurement, Illinois Department of Administrative Services (February 16, 1979) and telephone conversation with Mr. Lohrenz (March 15, 1979). According to Mr. Lohrenz, value incentive clauses have limited applicability because most of the energy-consuming goods purchased by a state are off-the-shelf standard items rather than items specially manufactured to fit particular needs.

66. Letter from John S. Babich, Chief of Procurement, California Department of General Services (February 21,1979 ).

67. Wyoming included a value incentive clause in a Call for Bids on the drilling of four groundwater monitor wells. Bid No. 0284-J (November 30, 1978). See Tether, supra note 64, at 49-56 for the U.S. General Services Administration's value incentive clause [GSA Form 2984 (October 1974)] and descriptions of two instances in which the agency accepted Value Change Proposals after manufacturers of computer room type air conditioners modified their products to achieve energy savings.

68. Manufacturers may not know how much energy is used to manufacture a product. Even if they do have the data, they may regard it as proprietary information, according to Vernon Newberry, Division of Purchasing, Florida Department of General Services. Telephone conversation with Mr. Newberry (April 4, 1979).

69. Telephone conversation with Vernon Newberry, Division of Purchasing, Florida Department of General Services (April 4, 1979).

70. Other procurement efforts involving products made from recovered materials include programs in California and Illinois to review specifications and standards to determine whether there is discrimination against products containing recovered materials.

71. Letter from Joseph J. Warnas, Director of Materials Management, Maricopa County, Arizona (March 19, 1979).

72. 42 U.S.C. $\$ 6962$. See notes 74 and 75 infra.

73. The statute defines "procuring agency" as "any Federal agency, or any State agency or agency of a political subdivision of a State which is using appropriated Federal funds for such procurement, or any person contracting with any such agency with respect to work under such contract." 42 U.S.C. \$ 6903 (17). Procuring agencies must "comply with the requirements set forth in this section, with respect to any purchase or acquisition of a procurement item where the purchase price of the item exceeds $\$ 10,000$ or where the quantity of such items or of functionally equivalent items purchased or acquired in the course of the preceding year was $\$ 10,000$ or more." 42 U.S.C. \$ $6962(a)$. The law requires "each procuring agency [to] procure 
items composed of the highest percentage of recovered materials practicable consistent with maintaining a satisfactory level of competition. The decision not to procure such items shall be based on a determination that such procurement items (i) are not reasonably available within a reasonable period of time; (ii) fail to meet the performance standards set forth in the applicable specifications or fail to meet the reasonable performance standards of the procuring agencies; or (iii) are only available at an unreasonable price." 42 U.S.C.S 6962(c)(1)(A).

For all practical purposes, the preconditions (the definition that includes state and local procurement of fices within the meaning of "procurement agency" only if they are procuring with earmarked federal funds and the $\$ 10,000$ minimum) will limit the number of instances in which these of fices will have to comply with the requirement to purchase items composed of recovered materials. According to John Heffelfinger of the Resource Recovery Division of the Environmental Protection Agency, this procurement requirement will affect states most directly when they buy construction materials for federally-funded highways.

74. 42 U.S.C. $\$ 6962$ (e) requires the Environmental Protection Agency to "prepare ... guidelines for the use of procuring agencies in complying with the requirements of this section. Such guidelines shall set forth recommended practices with respect to the procurement of recovered materials and items containing such materials and shall provide information as to the availability, sources of supply and potential uses of such materials and items."

75. Telephone conversation with John Heffelfinger, Resource Recovery Division, Office of Solid Waste, U.S. Environmental Protection Agency (March 28, 1979).

76. Cal. Gov't Code $\$ 14784.6$. 


\section{BIBLIOGRAPHY}

American Bar Association. A Model Procurement Code for State and Loral Governments. Washington, D.C.: American Bar Association (February 1, 1979).

Council of State Governments. State and Local Government Procurement. Lexington, Ky.: Council of State Governments (1975).

Dumagan, Jesus C. "Optimal Replacement and Minimum Life Cycle Costs of a Chain of Equipments in an Infinite Horizon Model." Submitted by Minnesota Energy Agency as part of Minnesota's energy conservation plan (February 1978).

"Energy Efficient Purchasing Manual for Georgia's Local Governments." Prepared by the Georgia Office of Energy Resources, 270 Washington St., Atlanta, Ga. 30334 (1978).

"Guide to Efficient Lighting." Prepared by Energy Coordinator, Division of Purchase and Property, New Jersey Department of the Treasury, CN 039, Trenton, N.J. 08625 (n.d.).

Hall, Nicholas P. "Procedure for Energy Efficient Procurement." Prepared by Illinois Purchasing Division, Energy Resources Group, 801 Stratton Building, Springfield, Ill. 67206 (1978).

Life Cycle Costing Emphasizing Energy Conservation-Guidelines for an Investment Analysis. ERDA 76/130. Prepared for the U.S. Energy Research and Development by Reynolds, Smith \& Hills, ArchitectsEngineers-Planners, Inc., Jacksonville, Florida. (September 1976, revised May 1977). Available from National Technical Information Service, U.S. Department of Commerce, 5285 Port Royal Road, Springfield, Va. 22161.

"Life Cycle Costing in the Procurement of Electric Ranges." NBS-GCRETIP 76-09. Prepared for the Experimental Technology Incentives Program, National Bureau of Standards, Washington, D.C. 20234 (1976).

"Life Cycle Costing in the Procurement of Refrigerators-Freezers." NBSGCR-ETIP 76-10. Prepared for the Experimental Technology Incentives Program, National Bureau of Standards, Washington, D.C. 20234 (1976).

"Life Cycle Costing in the Procurement of Window Air Conditioners-Second Procurement." NBS-GCR-ETIP 76-19. Prepared for the Experimental Technology Incentives Program, National Bureau of Standards, Washington, D.C. 20234 (1976).

"Life Cycle Costing Procurement Case 1 Room Air Conditioners." Issued by the Federal Supply Service, General Services Administration, Crystal Mall Building 4, Washington, D.C. 20406 (1975). 
"Life Cycle Costing Procurement Case 2 Water Heaters." Issued by the Federal Supply Service, General Services Administration, Crystal Mall Building 4, Washington, D.C. 20406 (1975).

"Life Cycle Costing Procurement Case 3 Gas Ranges." Issued by the Federal " Supply Service, General Services Administration, Crystal Mall Building 4, Washington, D.C. 20406 (1975).

"Life Cycle Costing Procurement Case 4 High-Speed Printer Ribbons." Issued by the Federal Supply Service, General Services Administration, Crystal Mall Building 4, Washington, D.C. 20406 (1975).

Life Cycle Costing Workbook. Issued by the Federal Supply Service, General Services Administration, Crystal Mall Building 4, Washington, D.C. 20406 (n.d.).

Manchester, Russell M. and Bergstrom, Robert P. Energy Efficiency in : Purchasing Summary Report. Prepared by the Oregon Department of General Services, Purchasing Division and the Oregon Department of Energy, Conservation Division, Salem, Oregon 97310 (October 1978).

"Manual for Selecting Room Air Conditioner Size." Prepared by Energy Coordinator, Division of Purchase \& Property, New Jersey Department of the Treasury, CN 039, Trenton, N.J. 08625 (n.d.).

Runke, James F. and Elstein, Steven L. "State Initia tives to Achieve Energy Efficient Procurement: A Preliminary Report." Presented to 33rd Annual ' Meeting of the National Association of State Purchasing Officials, October 1978. Lexington, Ky.: Council of State Governments (1978).

Tether, Ivan J. Government Procurement and Operations. Cambridge, Mass.: Ballinger (1 $\overline{977})$.

"Value Incentive Program--Computer Room Air Conditioning Units." NBSGCR-ETIP 76-23. Prepared for the Experimental Technology Incentives Program, National Bureau of Standards, Washington, D.C. 20234 (1976).

"Value Incentive Program--Energy Conservation Compressors for Computer Room Air Conditioning Systems." NBS-GCR-ETIP 76-26. Prepared for the Experimental Technology Incentives Program, National Bureau of Standards, Washington, D.C. 20234 (1976). 


\section{TECHNICAL APPENDIX}

In an effort to help close the information gap, this appendix contains life cycle cost formulae for a variety of energy-consuming products. The E'nvironmental Law Institute has not evaluated these formulae to determine their soundness and offers them only as examples of what some states have done. For further information about the formulae, contact the person or office listed.

\section{ARKANSAS}

Life Cycle Cost Formulae for:

Copying Machines

Ice Machines

Incandescent and Flourescent Lamps

Heat Pumps

Tractors

Typewriters

For further information, contact:

Office of State Purchasing

Arkansas Department of Finance and Administration

P.O. Box 2940

Little Rock, Arkansas 72203 
Life Cycle Cost Award Formula

For

Copying Machines

$\mathrm{EC}=\mathrm{P}+(\mathrm{A}+\mathrm{B}+\mathrm{C}+\mathrm{D}) \mathrm{K}$

Where: $\quad \mathrm{EC}=$ Total evaluated cost $(\$)$ over the anticipated life of the copying machine.

P, = Bid price (\$).

$A=$ Electricity consumed by machine while warming up (watts).

$\mathrm{B}=$ Electricity consumed by machine while copying (watts).

$\mathrm{C}=$ Electricity consumed by machine while on stand-by (watts).

$\mathrm{D}=\quad$ Electricity consumed by machine at any time other than the above (watts).

$\mathrm{K}=$ Cost of electricity (\$ per watt-hour).

Calculation of A, B, C, and D:

$$
\begin{aligned}
& A=\mathrm{Wl}[(\mathrm{L} \times \mathrm{T} 1)+(\mathrm{Z}-\mathrm{L}) \mathrm{T} 2] / 3600^{*} \\
& \mathrm{~B}=\mathrm{W} 2[\mathrm{Z}(\mathrm{T} 3+\mathrm{T} 4) / 3600+[(\mathrm{Q}-\mathrm{Z})+\mathrm{M}] / 60] \\
& \mathrm{C}=\mathrm{W} 3[\mathrm{~T} 5 \times \mathrm{Z}] / 3600 \\
& D=\text { either } \\
& \mathrm{W} 4(\mathrm{H}-[(\mathrm{L} \times \mathrm{Tl})+(\mathrm{Z}-\mathrm{L}) \mathrm{T} 2+(\mathrm{T} 3+\mathrm{T} 4) \mathrm{Z}+(\mathrm{T} 5 \times \mathrm{Z})] / 3600-[(\mathrm{Q}-\mathrm{Z})+\mathrm{M}] / 60) \\
& \text { or } \\
& \mathrm{W} 3(\mathrm{H}-[(\mathrm{L} \times \mathrm{T} \mathrm{l})+(\mathrm{Z}-\mathrm{L}) \mathrm{T} 2+(\mathrm{T} 3+\mathrm{T} 4) \mathrm{Z}+(\mathrm{T} 5 \times \mathrm{Z})] / 3600-[(\mathrm{Q}-\mathrm{Z})+\mathrm{M}] / 60) \\
& \text { or }
\end{aligned}
$$

0 for machines that automatically shut off completely af ter use.

Where: $L=$ Machine life (days).

$$
\mathrm{H}=\text { Machine life (hours). }
$$

*This formula and some of the following formulae in this appendix have been rewritten into equivalent forms more convenient to type. 
$M=$ Rate of production (copies/minute).

$\mathrm{Q}=$ Number of copies to be produced during life of machine.

$\mathrm{Z} \quad=\quad$ Number of machine operations during its life.

Tl = Time required for initial warm-up each day (seconds).

T2 = Time required for additional warm-ups for each operation of machine (seconds).

T3 = Time required to produce first copy (seconds).

$\mathrm{T} 4=$ Time required before machine goes on standby af ter producing the final copy of each run (seconds).

T5 = Time machine is on standby before automatically shutting of or reducing power (seconds).

W1 = Power consumption while warming up (watts/hour).

$\mathrm{W} 2=$ Power consumption while copying (watts/hour).

W3 $=$ Power consumption while on standby (watts/hour).

W4 = Power consumption while on reduced power (watts/hour).

$3600=$ Constant, used to convert time from seconds to hours.

$60:=$ Constant, used to convert time for minutes to hours. 
All bids meeting the requirements of this Invitation to Bid will be evaluated on the basis of life cycle cost. Bidders are not responsible for the calculation of the life cycle cost but must submit the following information with the bid in order for the bid to be considered.

1. Time required for initial warm up each day: seconds.

2. Warm up time required for each machine operation af ter the initial warm up: seconds.

3. Electricity consumption during warm up: watts per hour.

4. Time required for machine to produce 1 st copy af ter warm up: seconds.

5. Rate of production: copies per minute.

6. Time before machine goes on standby after producing last copy: seconds.

7. Electricity consumption while copying: watts per hour.

8. Electricity consumption while on standby: watts per hour.

9. Af ter copying, does the machine:
a. Automatically shut off completely?
b. Automatically reduce power?
c. Remain on standby until used again?

10. Time machine is on standby before automatically shutting off or reducing power: seconds.

11. Electricity consumption while on reduced power: watts per hour.

If there is any additional energy consumption information that you feel should be considered in evaluating your bid, indicate below: 
Life Cycle Cost Award Formula

For

Ice Machines

$E C=P+[C \times(W / 100) \times L] K$

Where: $\quad \mathrm{EC}=$ Total evaluated cost $(\$)$ over the anticipated life of the machine.

$\mathrm{P} \quad=\quad$ Bid Price $(\$)$.

$\mathrm{C}=$ Estimated ice consumption (pounds/day).

$\mathrm{W}=$ Electricity consumption in kilowatt-hours per 100 pounds of ice.

$100=$ Constant used to convert electricity consumption to kilowatt. hours per pound of ice.

$\mathrm{L}=$ Expected life of machine in days.

$\mathrm{K}=$ Estimated cost of electricity in \$/kilowatt-hour.

Life Cycle Cost Award Formula

For

Incandescent and Fluorescent Lamps

$\mathrm{EC}=(2600 / \mathrm{H}) \times \mathrm{P}+(\mathrm{W} \times \mathrm{K} \times 2600)$

Where: $\quad E C=$ Total evaluated cost $(\$)$ over a period of one year.

$2600=$ Estimated hours of use for one year.

$\mathrm{H}=$ Rated hours of life.

$P=$ Bid price $(\$)$.

$W=$ Watts.

$K=$ Cost of electricity in \$/watt-hour. 
Life Cycle Cost Award Formula

For

Single Package Heat Pumps

$$
\begin{aligned}
& E C=P+R_{c} \times K \times 12,000 / E E R+\left(R_{h} / 3.413\right) \times K \times 10,800 / . C O P \\
& \text { Where: }, E C=\text { Total evaluated cost }(\$) \text { over the anticipated life } \\
& \text { of the heat pump.' } \\
& \mathrm{P} \quad=\quad \text { Bid price }(\$) \text {. } \\
& R_{c}=\quad \text { Rated cooling capacity of the unit (thousand Btu's). } \\
& \mathrm{K}=\text { Cost of electricity }(\$ / \mathrm{Kwh}) \text {. } \\
& 12,000=\text { Total cooling hours over.the anticipated life of the } \\
& \text { heat pump. } \\
& \text { EER = Energy Efficiency Ratio. } \\
& R_{h} \quad=\quad \text { Rated heating capacity of the unit (thousand Btu's) } \\
& \text { at } 47^{\circ} \mathrm{F} \text { outdoor temperature. } \\
& 3.413=\text { Constant used to convert Btu's to kilowatts. } \\
& \text { ( } 1 \mathrm{kw}=\text { '413 Btu's). } \\
& 10,800=\text { Total heating hours over the anticipated life of the } \\
& \text { heat pump. } \\
& . C O P=\text { Coefficient of Performance of the heat pump at } \\
& 47^{\circ} \mathrm{F} \text { outdoor temperature. }
\end{aligned}
$$


Life Cycle Cost Award Formula

For

Tractors

LCC = U.P. + (F.C.) (F.U.) (H.O.) (Hp.C.)

Where: $\quad$ LCC $=\quad$ Total Life Cycle Cost.

U.P. = Tractor unit price (Bid Price).

F.C. = Fuel cost in \$/gal.

F.U. = Fuel used in gal./hour. This value shall be as per the "Nebraska Tractor Test" performance data. The fuel used shall be based on the "75\% of Pull at Maximum Power-Drawbar Performance" test condition. A copy of the "Nebraska Tractor Test" report shall be required with the bid.

H.O. = Useful life (hours operated) of the tractor in hours.

Hp.C. = Horse power correction factor is equal to the nominal horsepower divided by the actual horsepower as determined by the "Nebraska Tractor Test." Example: The Invitation to Bid required "maximum drawbar horsepower" of 35 h.p. or greater. From the "Nebraska Tractor Test" tractors $A$ and $B$ produce 35.50 and 42.20 "maximum drawbar horsepower" respectively.

Hp.C. for Tractor $A=35 / 35.50=0.986$

Hp.C. for Tractor $B=35 / 42.20=0.829$ 
Life Cycle Cost Award Formula

For

Single Element Typewriter

$E C=P+(W \times K \times H)+(E \times Q e \times Y)+(R \times Q r \times Y)$

\begin{tabular}{|c|c|c|c|}
\hline \multirow[t]{4}{*}{ Where: } & $\mathrm{EC}$ & $=$ & $\begin{array}{l}\text { Total evaluated cost }(\$) \text { over the anticipated life } \\
\text { of the machine. }\end{array}$ \\
\hline & $\mathbf{P}$ & $=$ & Bid price $(\$)$ of the machine. \\
\hline & W & $=$ & $\begin{array}{l}\text { Electricity consumption of machine during } \\
\text { operation (watts/hour). }\end{array}$ \\
\hline & $\mathrm{K}$ & $=$ & Cost of electricity per watt/hour. \\
\hline \multirow[t]{6}{*}{. } & $\mathrm{H}$ & $=$ & Life of machine in hours. \\
\hline & E & $=$ & Element cost. \\
\hline & $\mathrm{Qe}$ & $=$ & Quantity of elements used per year. \\
\hline & $\mathrm{Y}$ & $=$ & Life of machine in years. \\
\hline & $\mathrm{R}$ & $=$ & Ribbon cost. \\
\hline & $\mathrm{Qr}$ & $=$ & Quantity of ribbons used per year. \\
\hline
\end{tabular}

CALIFORNIA

Life Cycle Cost Formulae for:

Air Conditioners
Heat Pumps
Refrigerators, Freezers, Refrigerator-Freezers

For further information, contact:

State Office of Procurement

California Department of General Services

P.O. Box 1612

Sacramento, California 95807 
Air Conditioners

AGENCY CODE

P.E. NO.

Bid award will be based on lowest bid including energy usage and life cycle costing. Line item(s) are to be computed using life cycle costing method based on projected energy usage.

A copy of the manufacturer's technical data sheet listing electrical information pertaining to operational line voltage, ampere, wattage, BTU output, and E.E.R. for the models offered shall be submitted with the bid.

1. Date supplied by vendor. Make Model

a. BTU/Hour Unit Offered for Bid = BTU/Hour.

b. Certified Energy Efficiency Rating of Unit Offered for Bid = E.E.R. $=\frac{\text { BTU/Hours }}{\text { watts input }}$.

FOR STATE USE: BID EVALUATION METHOD

2. Data supplied by the State.

a. Life $=$ years/useful life.

b. Operating Hours per Year $=$

c. $\quad$ Electrical Price $=$ hours/year. $\$$ /watt-hour.

3. Formula for energy cost, life cycle energy cost.

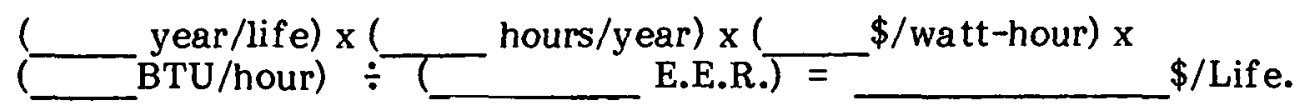

To Calculate Life Cycle Bid:

4. Subtract discounts (as applicable) from initial line item unit bid to determine the adjusted bid price.

a. $\quad\left(\frac{\text { Initial bid price })}{\text { Adjusted Bid Price. }}\left(L_{\text {Discounts }}\right)=(\right.$

5. Add adjusted bid price (4a.) to life cycle energy cost (3) to get total life cycle bid price per unit.

$\left(\$ \_\right.$_ adjusted bid price $)+(\$$ $\$$ total life cycle bid price per unit. life cycle energy cost) $=$ 
Heat Pumps

AGENCY CODE

P.E. NO.

Bid award will be based on lowest bid including energy usage and life cycle costing. Line item(s) are to be computed using life cycle costing method based on projected energy usage.

A copy of the manufacturer's technical data sheet listing electrical information pertaining to operational line voltage, ampere, wattage, BTU output, BTU input, C.O.P. and E.E.R for the models offered shall be submitted with the bid.

Testing Methods shall be as outllined in: California Administrative Code; Title 20, Chapter 2, Subchapter 4: Energy Conservation, Article 4: Appliance Efficiency Standards.

1. Vendor Supplied Data.

Make Model
a. BTU/hour (Heating)*
b. BTU/hour (Cooling)
c. C.O.P.
d. E.E.R.

*BTU/hour of heating by pump only, do not include heat strips for evaluation.

FOR STATE USE: BID EVALUATION METHOD

2. Data supplied by the State.
a. $\quad$ Life $=$ years/useful life.
b. Operating Hours per year: hours/year (heating), hours/year (cooling).
c. Electrical Price $=$ \$/watt-hour.
d. $1 \mathrm{kwh}=3412 \mathrm{BTU}$.

3. Formula for energy cost (HEATING).

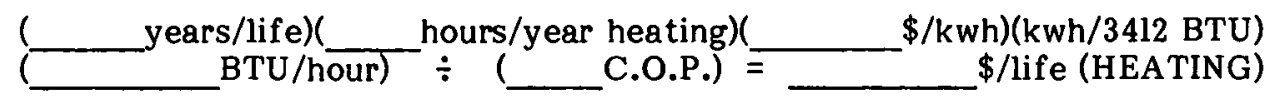

4. Formula for energy cost (COOLING).

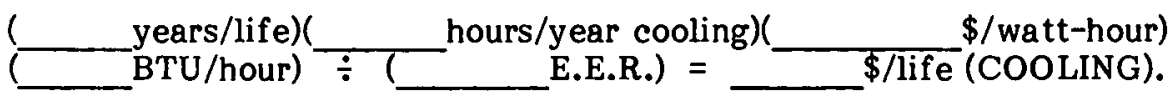

To Calculate Life Cycle Bid:

5. Subtract discounts (as applicable) from initial line item unit bid price to determine the adjusted bid price.
a.
Initial bid price) Discounts) $=$ ) Adjusted
b. Adjusted bid) + cooling) $=$ Bid Price. $\$ /$ Life heating $)+$ \$ Total LCC/unit. $\$ /$ Life 
Refrigerator, Freezers, Refrigerator-Freezers

AGENCY CODE

P.E. NO.

Bid award will be based on lowest bid including energy usage and life cycle costing. Line item(s) based on projected energy usage.

A copy of the manufacturer's technical data sheet listing electrical information pertaining to operational line voltage, ampere, wattage, cubic feet, and kilowatt consumption per month for the models offered shall be submitted with the bid.

The following method will be used to determine the life cycle cost of each applicable line items.

(l) Data supplied by the State to determine energy cost constant.
a. $\quad$ Life $=$ years/useful life.
b. Operating months per year =
c. Electrical price $=$
d. Energy cost constant $=$ (hour $)=$ year/life $) \times($ months/year $) \times($ \$ per kilowatt-hour. months/year. $\$$-month/kilowatt/useful life. \$-month/kilowatt/useful life. \$/kilowatt-

(2) Data supplied by vendor. Make Model
a. Refrigerated volume = food compartment area/cubic feet) =

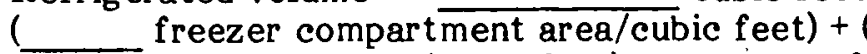 cubic feet/area. feet/area.
b. Certified energy consumption rating = refrigerated volume/cubic fresh kilowatt hours per month.

For units with anti-sweat switches, average the energy consumption with the switch in both the lowest and highest positions.

To Calculate Life Cycle Bid:

(3) Subtract discounts (as applicable) from initial line item unit bid price to determine the adjusted bid price.
a. ( Initial bid price $)-($ Discounts $)=($ ) Adjusted

(4) Multiply energy cost constant (__ _ (_ ) times kilowatt-hour consumption

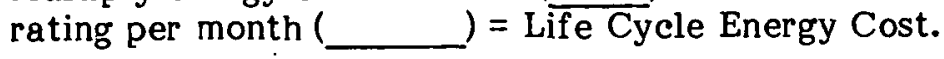
a. (_ \$-month/kilowatt/useful life) $\times($ sumption rating per month) $=\$$ kilowatt-hour con- Life Cycle Energy Cost.

(5) Add adjusted bid price (3a.) to total life cycle energy cost (4a.) to get life cycle bid price per unit.
a. $\quad(\$$ $=\$$ Adjusted bid price $)+(\$$ Life Cycle Bid Price (per unit). Lifè cycle energy cost)

(6) Multiply (per unit) cost (5a.) by line item quantity for line item cost. 
KENTUCKY

Life Cycle Cost Formulae for:
Automobiles
Clothes Dryers
Clothes Washers
Electric Ranges
Fluorescent Ballasts

For further information, contact:

Harold M. Staton

Executive Department for Finance and Administration Division of Purchases

New Capitol Annex

Frankfort, Ky. 40601

(502) 564-4917 
Method of Award. The award shall be to the responsive bidder with the lowest life cycle cost. The life cycle cost shall be equal to the unit price plus the fuel cost for 60,000 miles minus the resale value af ter four years.

$$
\text { LCC }=\text { U.P. }+60,000 / \text { E.P.A. } \times \text { F.C. }-(\text { R.F. }) \times(\text { U.P. })
$$

Where:

$$
\begin{array}{ll}
\text { LCC }= & \text { Life cycle cost } \\
\text { U.P. }= & \text { Unit Price (bidder's price) } \\
\text { E.P.A. }=\quad \begin{array}{l}
\text { Environmental Protection Agency's fuel consumption } \\
\text { rating for the automobile bid }
\end{array} \\
\text { F.C. = } \quad \begin{array}{l}
\text { Fuel cost as determined by the Division of Purchases } \\
(\$ / g a l .)
\end{array} \\
\text { R.F. = } \quad \begin{array}{l}
\text { Resale factor based on N.A.D.A. official used car guide. } \\
\text { R.F. is equal to the "Average Trade In" (four years old) } \\
\text { divided by Manufacturer's suggested advertised delivered } \\
\text { price, (Factory A.D.P.), all values corrected to a common } \\
\text { year dollar based on the consumer price index. R.F. shall } \\
\text { be determined by the Division of Purchases by using an } \\
\text { automobile with similar characteristics, (i.e. Nova for } \\
\text { Nova, Hornet for Concord, etc.) for each unit. }
\end{array}
\end{array}
$$




\section{CLO'THES DRYERS}

\section{Energy Consumption - Dryers - Electric}

The energy consumption per month (kilowatt hours/month) shall be determined per testing procedures and conditions as outlined and defined in AHAM standard HLD$2 \mathrm{EC}$.

\section{Life Cycle Cost - Dryers - Electric}

The Life Cycle Cost shall be equal to the unit cost plus the cost of the energy to operate the dryer for five (5) years.

$$
\begin{aligned}
& \text { LCC = U.P. + (E.C.)(E.U.)(N.M.) where } \\
& \begin{aligned}
\text { LCC } & =\text { Life Cycle Cost } \\
\text { UP } & =\text { Unit Price } \\
\text { EC } & =\text { Energy Cost in } \$ / \mathrm{KWH} \text { (supplied by buyer) } \\
\text { EU } & =\text { Energy Used in KWH/Month (Per AHAM HLD-2EC) } \\
\mathrm{NM} & =\text { Number of Months (equals } 60 \text { months for five years) }
\end{aligned}
\end{aligned}
$$

EC shall be equal to per kilowatt hour.

\section{Energy Consumption - Dryers - Gas}

The energy consumption per month (BTU/month) shall be determined per testing procedures and conditions as outlined and defined in AHAM standard HLD-2EC.

\section{Life Cycle Cost - Dryers - Gas}

The Life Cycle Cost shall be equal to the unit cost plus the cost of the energy to operate the dryer for five (5) years.

$$
\begin{aligned}
& \text { LCC = U.P. + (E.C.)(E.U.)(N.M.) where } \\
& \begin{aligned}
\text { LCC } & =\text { Life Cycle Cost } \\
\text { UP } & =\text { Unit Price } \\
\text { EC } & =\text { Energy Cost in } \$ / B T U \text { (supplied by buyer) } \\
\text { EU } & =\text { Energy Used in BTU/month (per AHAM HLD-2EC) } \\
\text { NM } & =\text { Number of Months (equals } 60 \text { months for five years) }
\end{aligned}
\end{aligned}
$$

EC shall be equal to per 100,000 BTU. 


\section{CLOTHES WASHERS}

\section{Energy Consumption - Clothes Washer}

The energy consumption per month (BTU/month) shall be determined per testing procedures and conditions as outlined and defined in AHAM standard HLW-2EC.

\section{Life-Cycle Cost - Clothes Washer}

The Life Cycle Cost shall be equal to the unit cost plus the cost of the energy to operate the washer for five (5) years.

$$
\text { LCC = U.P. + (E.C.)(E.U.)(N.M.) }
$$

where

$$
\begin{aligned}
& \text { LCC = Life-Cycle Cost } \\
& \text { U.P. = Unit Price } \\
& \text { E.C. = Energy Cost in \$/BTU (supplied by buyer) } \\
& \text { E.U. = Energy Used in BTU/Month (per AHAM HLW-2EC) } \\
& \text { N.M. = Number of Months (equals } 60 \text { months for five years) }
\end{aligned}
$$

E.C. shall be equal to per $100,000 \mathrm{BTU}$. 


\section{LCC - ELECTRIC RANGES}

The Life Cycle Cost of an electric range shall be equal to the unit price plus the cost of operation for five (5) years.

$$
\text { L.C.C. = U.P. + C.O. }
$$

where

$$
\begin{aligned}
& \text { L.C.C. }=\text { The Life Cycle Cost } \\
& \text { U.P. }=\text { Unit Price } \\
& \text { C.O. }=\text { Cost of Operation for five years }
\end{aligned}
$$

The Cost of Operation for five years (C.O.) shall be equal to

$$
\text { C.O. }=\left(\text { Ens } / \text { Eff }_{\mathrm{T}}\right)(5 \text { yrs./life })(\$ .00004 / \text { watt hour }) \text {. }
$$

where

$$
\begin{aligned}
& \text { Ens }=\begin{aligned}
= & \text { The energy required per year for the surface units of the range } \\
& =783000 \text { watts-hours. }
\end{aligned} \\
& \text { Eff }_{\mathrm{T}}=\text { The average efficiency of the surface units }
\end{aligned}
$$

where

$$
\operatorname{Eff}_{T}=\left[\left(\operatorname{Eff}_{1}\right)\left(\mathrm{H}_{1}\right)+\left(\operatorname{Eff}_{2}\right)\left(\mathrm{H}_{2}\right)+\left(\operatorname{Eff}_{3}\right)\left(\mathrm{H}_{3}\right)+\left(\operatorname{Eff}_{4}\right)\left(\mathrm{H}_{4}\right)\right] /\left[\mathrm{H}_{1}+\mathrm{H}_{2}+\mathrm{H}_{3}+\mathrm{H}_{4}\right]
$$

and

$\mathrm{Eff}_{1}, \mathrm{Eff}_{2}, \mathrm{Eff}_{3}$, and $\mathrm{Eff}_{4}$, are the efficiencies of the four surface units as defined by AHAM ER-1 (ANSI C71.1-1972).

$\mathrm{H}_{1}, \mathrm{H}_{2}, \mathrm{H}_{3}, \mathrm{H}_{4}$, are the maximum inputs to the four surface units.

Bidder shall supply the following*

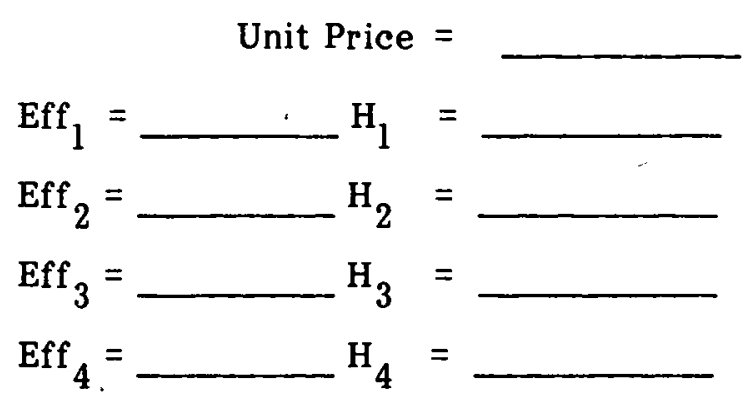

*Failure to supply efficiency data per AHAM ER-1 may be cause for rejection of the bid. 
$-52-$

Bidder may supply the following

$$
\begin{aligned}
\operatorname{Eff}_{\mathrm{T}} & = \\
\text { C.O. } & = \\
\text { L.C.C. } & =
\end{aligned}
$$

*Award shall be based on this total. 
LCC - FLUORESCENT BALLASTS

The award shall be to the lowest total relative cost to the Commonwealth as outlined and defined in Table I titled "Ballast Life Cycle Cost". The total relative cost is the sum of the unit cost and the energy cost of the five (5) items, each item being prorated based on predicted Commonwealth purchases. Details and requirements for completion of Table I are included in sections titled "Notes" and "Special Notes to Bidders". The buyer shall complete columns titled "Lamp Description", "Voltage", and "Purchase Factor". The bidder shall complete columns titled "Ballast Catalog Number", "Input Watts", and "Unit Cost". The bidder may complete columns titled "Energy Cost", "Total Cost", "Relative Cost", and item titled "Total Relative Cost".

\section{NOTES:}

(1) The bidder shall fill in the ballast catalog number in this column. The ballast shall be CBM certified for full light output for the application described. The ballast shall be Class $\mathrm{P}$. The bidder shall furnish an independent laboratory report, ETL, or equal, as verification.

(2) Input Watts shall be per CBM specifications and therefore, per ANSI C82.1 and ANSI C82.2. The bidder shall furnish an independent laboratory report, ETL or equal, as verification of the input watts.

(3) Energy cost shall be equal to $\$ .624$ per input watt. The value "\$.624 per input watt" is based on 15,600 operating hours and $\$ .04 / \mathrm{KWH}$. The bidder shall multiply the input watts (NOTE: (2)) by $\$ .624$ to determine the energy cost.

\section{Energy Cost $=\$ .624 \times$ input watts}

(4) Unit cost shall be the unit ballast cost after application of the discount factor.

$$
\text { Unit Cost }=(1.0-\text { Discount from List }) \times \text { List Price }
$$

(5) Total cost is the sum of the energy cost and the unit cost.

(6) Purchase factor is to be supplied by the buyer. The purchase factor is the percentage of each type of ballast purchased by the Commonwealth from the present price contract.

(7) The relative cost is equal to the total cost times the purchase factor. The contract award shall be to the bidder with the lowest total relative cost for all items. 


\section{SPECIAL NOTES TO BIDDERS:}

A. Failure to supply CBM certified full light output ballast

Bidder shall not list ballast which are not CBM certified full light output. If a bidder cannot list a CBM certified full light output ballast for each application, bidder shall place an "N.A." in the relative cost column for that application.

Failure to supply a CBM certified ballast for one (1) item shall not be cause for rejection of the bid. For purpose of evaluation of the total relative cost, the relative cost for the "N.A." item shall be set equal to 1.20 times the highest bid for that item.

Failure to supply a CBM certified ballast for two (2) or more items shall be cause for rejection.

B. Failure to supply an independent laboratory report, ETL, or equal

Failure to supply an independent laboratory report, ETL, or equal, shall be cause for rejection of the bid. In the event a bidder cannot supply an independent laboratory report prior to the bid opening date for a CBM certified ballast, the bidder may supply a notarized letter stating that "the ballast is CBM certified for full light output" and that the "input watts were determined per CBM specifications and therefore, per ANSI C82.1 and ANSI C82.2". Bidder shall furnish an independent laboratory report, ETL, or equal, for all items prior to award of price contract.

C. Definition of Terms

Input watts as used in this invitation shall be per ANSI C82.2, paragraph 3.2.1(3) power.

Full light output as used in this invitation shall be per ANSI C82.l, paragraph 5.3 . 


\begin{tabular}{|c|c|c|c|c|c|c|c|c|c|}
\hline $\begin{array}{l}\text { Item } \\
\text { No. }\end{array}$ & $\begin{array}{l}\text { Lamp } \\
\text { Description }\end{array}$ & Voltage & $\begin{array}{l}\text { Ballast } \\
\text { Catalog } \\
\text { Number : }\end{array}$ & $\begin{array}{l}\text { Input }^{(2)} \\
\text { Watts }\end{array}$ & $\begin{array}{l}\text { Energy }^{(3)} \\
\text { Cost }\end{array}$ & $\begin{array}{l}\text { Unit }{ }^{(4)} \\
\text { Cost } \\
\end{array}$ & $\begin{array}{l}\text { Total } \\
\text { Cost }\end{array}$ & $\begin{array}{l}\text { Purchase }^{(6)} \\
\text { Factor }\end{array}$ & $\begin{array}{l}\text { Relative } \\
\text { Cost }\end{array}$ \\
\hline 1. & (l)F $40 T 12 / R S$ & 120 & & & & : & & .04 & \\
\hline
\end{tabular}

Rapid Start 425/430 M.A. High Power Factor Two Lamp Ballast

\begin{tabular}{|c|c|c|c|c|c|c|c|c|c|}
\hline & $\begin{array}{l}\text { Lamp } \\
\text { Description }\end{array}$ & Voltage & $\begin{array}{l}\text { Ballast } \\
\text { Catalog } \\
\text { Number }\end{array}$ & $\begin{array}{l}\text { Input }^{(2)} \\
\text { Watts }\end{array}$ & $\begin{array}{l}\text { Energy } \\
\text { Cost }\end{array}$ & $\begin{array}{l}\text { Unit } \\
\text { Cost }\end{array}$ & $\begin{array}{l}\text { Total } \\
\text { Cost }\end{array}$ & $\begin{array}{l}\text { Purchase }^{(6)} \\
\text { Factor }\end{array}$ & $\begin{array}{l}\text { Relative } \\
\text { Cost }\end{array}$ \\
\hline 2. & (2)F40Tl2/RS & 120 & & & & & & .55 & . \\
\hline 3. & (2)F 40T12/RS & 277 & & & 冫 & & & .14 & \\
\hline
\end{tabular}

\begin{tabular}{|c|c|c|c|c|c|c|c|c|c|}
\hline & $\begin{array}{l}\text { Lamp } \\
\text { Description }\end{array}$ & Voltage & $\begin{array}{l}\text { Ballast } \\
\text { Catalog } \\
\text { Number } \\
\end{array}$ & $\begin{array}{l}\text { Input }^{(2)} \\
\text { Watts } \\
\end{array}$ & $\begin{array}{l}\text { Energy } \\
\text { Cost }\end{array}$ & $\begin{array}{l}\text { Unit }^{(4)} \\
\text { Cost } \\
\end{array}$ & $\begin{array}{l}\text { Total } \\
\text { Cost }\end{array}$ & $\begin{array}{l}\text { Purchase }^{(6)} \\
\text { Factor } \\
\end{array}$ & $\begin{array}{l}\text { Relative } \\
\text { Cost }\end{array}$ \\
\hline 4. & (2)F96 $12 / \mathrm{HO}$ & 120 & & & & & & .06 & \\
\hline
\end{tabular}

Slimline 425/430 M.A. High Power Factor Two Lamp Ballast

\begin{tabular}{|c|c|c|c|c|c|c|c|c|c|}
\hline & $\begin{array}{l}\text { Lamp } \\
\text { Description }\end{array}$ & Voltage & $\begin{array}{l}\text { Ballast } \\
\text { Catalog } \\
\text { Number }\end{array}$ & $\begin{array}{l}\text { Input }^{(2)} \\
\text { Watts } \\
\end{array}$ & $\begin{array}{l}\text { Energy } \\
\text { Cost }\end{array}$ & $\begin{array}{l}\text { Unit }^{(4)} \\
\text { Cost } \\
\end{array}$ & $\begin{array}{l}\text { Total } \\
\text { Cost }\end{array}$ & $\begin{array}{l}\text { Purchase }^{(6)} \\
\text { Factor } \\
\end{array}$ & $\begin{array}{l}\text { Relative } \\
\text { Cost }\end{array}$ \\
\hline 5. & (2)F96 Tl2 & 120 & & & & . & & .21 & \\
\hline
\end{tabular}

* Numbers in parenthesis refer to notes which explain requirements in completing data

** Award shall be made from this total

Total Relative Cost

Table 1. Ballast Life-Cycle Cost 
NORTH CAROLINA

Life Cycle Cost Formula for:
Air Compressors
Air Conditioners
Blanket Type Insulation for Walls
Copying Machines
Dehumidifiers
Dishwashers
Humidifiers
Ice Making Machines

For further information, contact:

\author{
Roger A. Lundquist \\ Energy Procurement Engineer \\ North Carolina Division of Purchase and Contract \\ Department of Administration \\ 116 West Jones Street \\ Raleigh, North Carolina 2761
}




\section{AIR COMPRESSORS, ELECTRIC \\ ENERGY EFFICIENCY COST CALCULATIONS}

Award of Contract: In addition to the normal considerations given to a contract of this nature such as specification compliance, price, delivery, service capabilities, etc., evaluation of proposals submitted will also include consideration of energy costs based on the formula below.

Formula:

Energy Efficient Cost $=[P+(W \times 250)] \times C_{n} / C$

$250=$ Constant based on 5,000 hours of use and $\$ .05 / \mathrm{KWH}$.

$\mathrm{W}=\mathrm{K} . \mathrm{W}$. to produce rated volume at rated pressure.

$\mathrm{C}=$ Actual rated compressor output volume (SCFM) at rated pressure.

$C_{n}=$ Nominal rated compressor output volume (SCFM) at rated pressure as noted on bid item description. 


\section{AIR CONDITIONING - WINDOW/WALL MOUNTED \\ ENERGY EFFICIENCY COST CALCULATION}

(Alternate Method)

Award of Contract: In addition to the normal considerations given to a contract of this nature such as specification compliance, price, delivery, service capabilities, etc., evaluation of proposals submitted will also include consideration of energy costs based on the formula below.

For mula:

Energy Efficient Cost $=\mathrm{P}+\mathrm{CO} / \mathrm{EER}$

$$
\begin{aligned}
\mathrm{P} & =\text { Bid price }(\$) \\
* \mathrm{CO} & =\text { Operating cost }-5 \text { years } \\
*^{*} \mathrm{EER} & =\text { Energy efficiency ratio (use higher EER on dual voltage models) } \\
* \mathrm{CO} & =\mathrm{R} \times \mathrm{H} \times \mathrm{K}
\end{aligned}
$$

Where: $\quad R=$ rated capacity in BTU $/ \mathrm{Hr}$.$$
\mathrm{H}=\text { operating hours }-5 \text { years }
$$$$
\mathrm{K}=\text { cost of electricity }-\$ / \text { watt } \mathrm{hr} \text {. }
$$

**EER (if not given by $\mathrm{mfr}$. ) = BTU rating/wattage

This Alternate Method may be used on a local basis for quick comparisons. It is not the same as the mandated federal method. 


\section{BLANKET TYPE INSULA'TION FOR WALLS}

\section{ENERGY EFFICIENCY COST CALCULATIONS}

Award of Contract: In addition to the normal considerations given to a contract of this nature such as specification compliance, price, delivery, service capabilities, etc., evaluation of proposals submitted will also include consideration of energy costs based on the for mula below.

Formula:

$$
\begin{aligned}
& \text { Energy Efficient Cost }=P-E_{S} \\
& P=\text { Purchase price for sufficient material to cover } 1000 \text { sq. } \mathrm{ft} \text {. } \\
& E_{S}=\text { Energy savings over five year period due to installing insulation. } \\
& \quad E_{S}=5,965 R_{I} /\left[R_{W} \cdot R_{I}+R_{W} \cdot R_{W}\right]
\end{aligned}
$$

Where: $\quad R_{I}=$ thermal resistance of the insulation. For use in this equation $R_{I}$ shall be in unit of hour $-\mathrm{ft}^{2}-{ }^{\circ} \mathrm{F} / \mathrm{BTU}$. (See Note 2)

$$
R_{W}=\text { thermal resistance of the wall without insulation in units of hour }-\mathrm{ft}^{2}
$$

5965 is a constant determined by the appropriate weather data, by the cost of energy, and by the investment payback period (3393 degree days, $\$ .05 / \mathrm{KWH}, 5 \mathrm{yrs}$.)

Notes: $\quad$ 1. $\quad R_{W}$, wall thermal resistance will be supplied by the buyer. If detailed information is not available on the wall construction, $\mathbf{R}_{W}$ shall be set equal to 2.50 (Typical wall construction with $1 / 2$ gypsum board, $1 / 2$ plywood, 4" facing brick, $35 / 8^{\prime \prime}$ void space.). Framing factor.has not been considered in determining $R_{W}$.

2. $\mathrm{R}_{\mathrm{I}}$, insulation thermal resistance, shall be supplied by the bidder. $\mathrm{R}_{\mathrm{I}}$ shall be based on an insulation blanket no thicker than $35 / 8^{\prime \prime}$, the void space in the wall, unless the specific wall construction is described. If the void space is less than the insulation thickness, $R_{I}$ shall be the thermal resistance of the insulation blanket when compressed to fit the void space.

3. The Energy Efficient Cost is calculated based on $1,000 \mathrm{ft}^{2}$ wall area. The bidder shall determine the cost for $1,000 \mathrm{ft}^{2}$ insulation for use in the formula. The bidder shall also quote the price for a standard unit of purchase (roll, etc.)

4. It is very possible the Energy Efficient Cost will be negative. This indicates that the insulation pays for itself in the five-year period. The award will be based on the largest negative or the lowest positive Energy Efficient Cost. 
COPYING MACHINES - PURCHASED

\section{ENERGY EFFICIENCY COST CALCULATIONS}

Award of Contract: In addition to the normal considerations given to a contract of this nature such as specification compliance, price, delivery, service capabilities, etc., evaluation of proposals submitted will also include consideration of energy costs based on the for mula below.

Formula:

Energy Efficient Cost $=\mathrm{P}+\mathrm{A}+\mathrm{B}$

$\mathrm{P}=\operatorname{Bid}$ price $(\$)$

$A=$ Cost of electricity used copying

$B=$ Cost of electricity used on standby (use zero for instant on machine)

Where: $A=(Q / C) \times E_{c} \times K$

$Q=$ Estimated copies to be produced per year

$\mathrm{C}=$ Rated production of copies per hour

$\mathrm{E}_{\mathrm{c}}=$ Electricity consumption of machine when copying - Watts/Hr.

$\mathrm{K}=$ Cost of electricity $-\$ / \mathrm{Watt}-\mathrm{Hr}$.

$B=(2600-Q / C) \times E_{s} \times K$

$\mathrm{Q}=$ Same as above

$\mathrm{C}=$ Same as above

$E_{S}=$ Electricity consumption of machine on standby - Watts/Hr.

$\mathrm{K}=$ Cost of electricity $-\$ / \mathrm{Watt}-\mathrm{Hr}$.

Note: $\quad$ Values for $\mathrm{C}_{,} \mathrm{E}_{\mathrm{c}}$ and $\mathrm{E}_{\mathrm{s}}$ must be supplied by bidder.

Cost calculated by formula above is for One Year.

Consideration must also be given to manufacturer's warranty.

It is assumed copier is turned off at end of business day. 


\section{DEHUMIDIFIERS}

\section{ENERGY EFFICIENCY COST CALCULATIONS}

\section{Energy Consumption}

Energy consumption shall be measured per test procedures and conditions as outlined and defined by the Department of Energy, Part 430 - Energy Conservation Program for Appliances, Test Procedures for Dehumidifiers, as reported in the Federal Register, Volume 42, No. 201 - Tuesday, October 18, 1977, beginning page 55608.

\section{Annual Operating Cost}

Annual operating cost shall be determined in accordance with paragraph 430.22 of the referenced test procedure.

Energy Efficient Cost For mula

***Energy Efficient Cost $=\mathrm{P}+(\mathrm{L} \times$ A.O.C. $)$

Where

P. = Unit Price

L. = Useful Life in years

A.O.C. = Annual operating cost as defined based on energy cost of

E.E.C. = Energy Efficient Cost

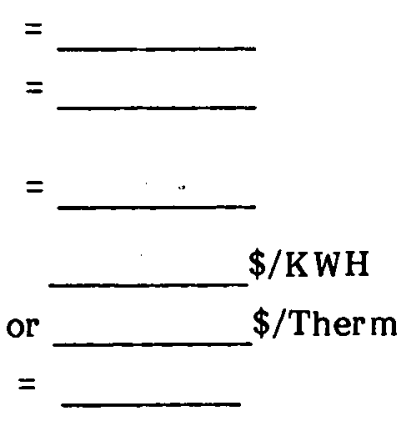

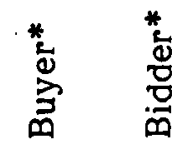

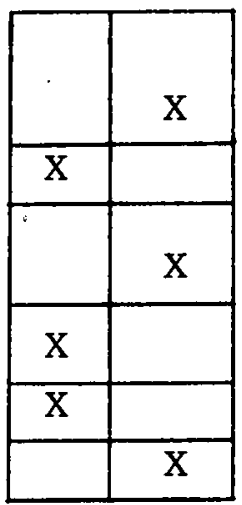

*Indicates responsibility for completing data.

**Calculations will be made for region II unless otherwise noted.

Award of Contract: In addition to the normal considerations given to a contract of this nature such as specification compliance, price, delivery, service capabilities, etc., evaluation of proposals submitted will also include consideration of energy costs based on the formula above. 
DISHW ASHER, DOMESTIC

ENERGY EFFICIENCY COST CALCULATIONS

\section{Energy Consumption}

Energy consumption shall be measured per test procedures and conditions as outlined and defined by the Department of Energy, Part 430 - Energy Conservation Program for Appliances, Test Procedures for Dishwashers, as reported in the Federal Register, Volume 42, No. 152 - Monday, August 8, 1977, beginning page 39964.

\section{Annual Operating Cost}

Annual operating cost shall be determined in accordance with paragraph $\mathbf{4 3 0 . 2 2}$ of the referenced test procedure.

Energy Efficient Cost For mula

* $\quad$ **nergy Efficient Cost $=\mathrm{P}+(\mathrm{L} \times \mathrm{A}$.O.C. $)$

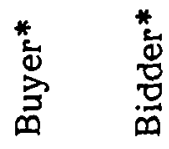

Where

P. = Unit Price

$L_{.}=$Useful Life in years

A.O.C. = Annual operating cost as defined based on energy cost of

E.E.C. = Energy Efficient Cost
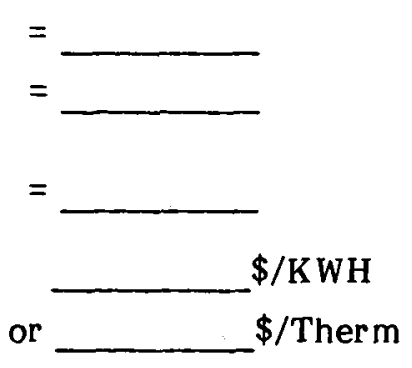

$=$

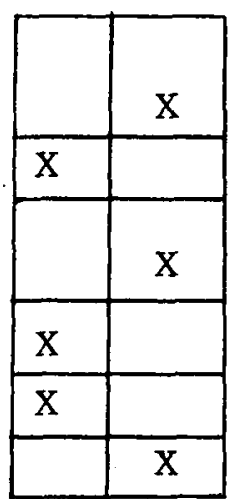

*Indicates responsibility for completing data.

**For general bid considerations, energy calculations will be made assuming use of electrically heated hot water.

Award of Contract: In addition to the normal considerations given to a contract of this nature such as specification compliance, price, delivery, service capabilities, etc., evaluation of proposals submitted will also include consideration of energy cost based on the formula above. 
HUMIDIFIERS (Room or Central)

ENERGY EFFICIENCY COST CALCULATIONS

\section{Energy Consumption}

Energy consumption shall be measured per test procedures and conditions as outlined and defined by the Department of Energy, Part 430 - Energy Conservation Program for Appliances, Test Procedures for Humidifiers as reported in the Federal Register, Volume 42, No. 201 - Tuesday, October 18, 1977, beginning page 55599.

\section{Annual Operating Cost}

Annual operating cost shall be determined in accordance with paragraph $\mathbf{4 3 0 . 2 2}$ of the referenced test procedure.

\section{Energy Efficient Cost Formula}

**Energy Efficient Cost $=$ P + (L x A.O.C.)

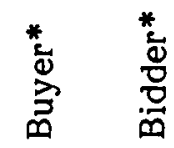

Where
P. = Unit Price
L. = Useful Life in years
A.O.C. = Annual operating cost as defined based on energy cost of

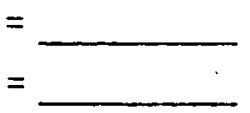

\begin{tabular}{|l|l|}
\hline & $X$ \\
\hline$X$ & \\
\hline & $x$ \\
\hline$x$ & \\
\hline$X$ & \\
\hline & $X$ \\
\hline
\end{tabular}
E.E.C. = Energy Efficient Cost

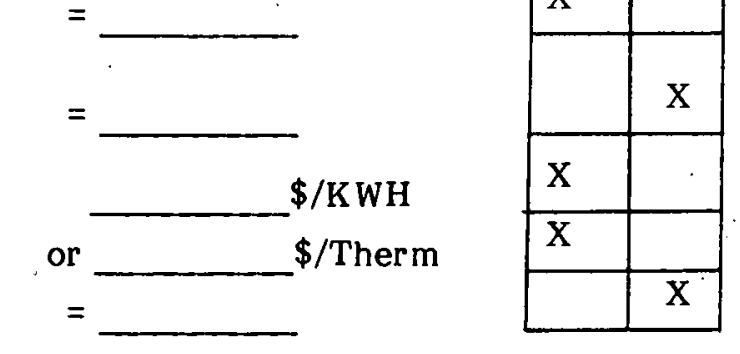

*Indicates responsibility for completing data.

**Calculations will be made for region II unless otherwise noted.

Award of Contract: In addition to the normal considerations given to a contract of this nature such as specification compliance, price, delivery, service capabilities, etc., evaluation of proposals submitted will also include consideration of energy costs based on the formula above. 
ICE MAKING MACHINES

\section{ENERGY EFFICIENCY COST CALCULATIONS}

Award of Contract: In addition to the normal considerations given to a contract of this nature such as specification compliance, price, delivery, service capabilities, etc., evaluation of proposals submitted will also include consideration of energy costs based on the formula below.

Formula:

Energy Efficient Cost $=[P+(W \times 91.25)] \times C_{n} / C$

$P=$ Bid price

$W=$ Electrical energy to produce actual rated ice capacity in kilowatts.

$\mathrm{C}=$ Actual rated capacity (lbs. of ice delivered in 24 hours)

$\mathrm{C}_{\mathrm{n}}=$ Nominal rated capacity (lbs. of ice delivered in 24 hours as noted in bid item description)

$91.25=$ Constant based on $\$ .05 / \mathrm{kwh}$ energy cost and 5 year service life 